History of Monetary Policy in India since Independence

Ashima Goyal

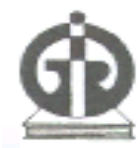

Indira Gandhi Institute of Development Research, Mumbai September 2011 http://www.igidr.ac.in/pdf/publication/WP-2011-018.pdf 


\title{
History of Monetary Policy in India since Independence
}

\author{
Ashima Goyal \\ Indira Gandhi Institute of Development Research (IGIDR) \\ General Arun Kumar Vaidya Marg \\ Goregaon (E), Mumbai- 400065, INDIA

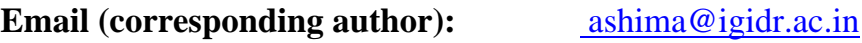

\begin{abstract}
An SIIO paradigm, based on structure and ideas that become engraved in institutions and affect outcomes, is developed to examine and assesses monetary policy in India after independence. Narrative history, data analysis, and reporting of research demonstrate the dialectic between ideas and structure. Exogenous supply shocks are used to identify policy shocks and isolate their effects. It turns out policy was sometimes exceedingly tight when the common understanding was of a large monetary overhang. Fiscal dominance made policy procyclical. But the three factors that cause a loss of monetary autonomy_governments, markets and openness - are moderating each other. Markets moderate fiscal profligacy and global crises moderate markets and openness. Greater current congruence between ideas and structure is improving institutions and contributing to India's better performance.
\end{abstract}

\section{Keywords:}

Monetary policy history, Structure, Ideas, Institutions, Outcomes, India

\section{JEL Code:}

E42, E5, E58, E63

\section{Acknowledgements:}

I thank the Professor P.R. Brahmananda Endowment Fund for the Award, professor Dr. R. S. Deshpande for his support, two referees for their very encouraging response, Dr. D.M. Nachane and Dr. Y.V. Reddy for useful discussions, TCA Srinivasa Raghavan for making an unpublished manuscript on pre-independence monetary history available to me, Shruti Tripathi and Reshma Aguiar for excellent research and secretarial assistance respectively. 


\section{Content page}

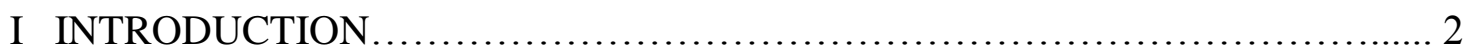

II STRUCTURE....................................................... 3

II.1 Sectors.......................................................... 3

II.2 Growth and inflation................................................

II.3 Politics............................................................ 7

II.4 Government finances..............................................9

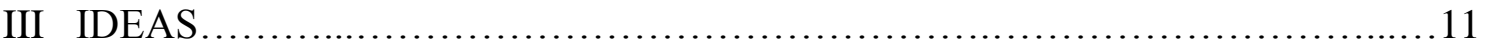

III.1 Keynes modified................................................11

III.2Monetarism in the aggregate.......................................13

III.3Globalization: Ideas and domestic impact............................15

III.4New Keynesian theories in emerging markets..........................19

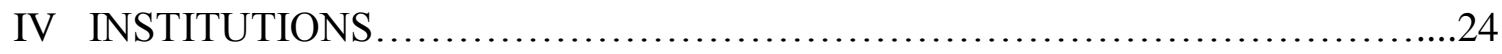

IV.1 Precedents and path dependence....................................25

IV.2 Strengthening institutions.............................................. 28

IV.3 Openness, markets and CB autonomy..............................30

IV.4 Bank Governors and Delegation in India................................. 32

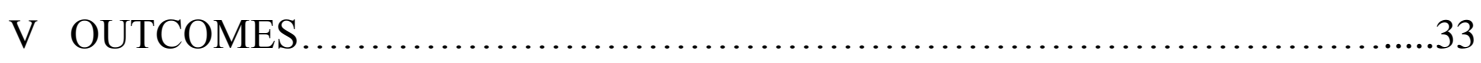

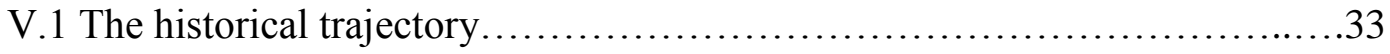

V.2 Excess demand or cost shocks? ................................... 36

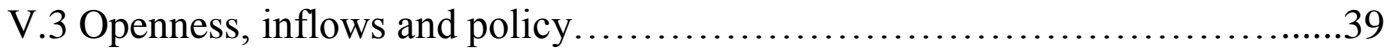

V.4 Money markets and interest rates.....................................43

V.5 The global crisis, response and revelation of structure...................47

V.6 Trends in money and credit......................................50

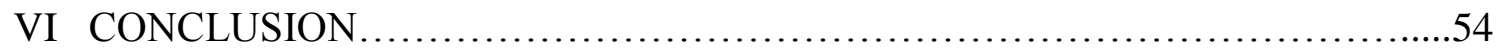




\title{
History of Monetary Policy in India since Independence
}

Paper written for the first Professor P.R. Brahmananda Memorial Research Award

\author{
Ashima Goyal
}

\section{Introduction}

The study examines and assesses monetary policy in India after independence in the context of interplay between domestic structure and external factors. Domestic structure includes economic and political structure, the demands of growth, poverty reduction, financial inclusion and the gradual development of institutions and markets. The external sector includes the dominant ideas of the time and their change, shocks such as oil and wars, dependence on foreign capital and the effect of greater opening out. Structure and ideas become engraved in institutions that affect outcomes. Instead of the structure, conduct, performance (SCP) paradigm used in the industrial organization literature, this is a SIIO paradigm.

The approach is very much in the tradition set by Dr. Brahmananda. He had himself undertaken a monumental study of Money, Income and Prices in $19^{\text {th }}$ Century India (2001). But starting with his early work (Vakil and Brahmananda, 1956), a defining characteristic of his approach was to refine analytical frameworks so that they became relevant for the analysis of Indian structure ${ }^{1}$.

In the study, narrative history, data analysis, and reporting of research are used to show the dialectic between ideas and structure. Policy outcomes are explained in the framework developed. Given the six decades over which the dialectic has played out, a broad brush approach is used that focuses on the main trends, rather than the day-today policy decisions that co-created the trends. But a flavour is given of intricate processes that generate the cold numbers.

\footnotetext{
${ }^{1}$ D.M.Nachane (2003) brings out, with great warmth and affection, both Dr. Brahmananda's scholarship and his focus on relevance.
} 
It is argued a greater congruence between ideas and structure in recent times contributed to improvements in institutions and to India's better performance. Policy moved from struggling with scarcity to having to deal with excess foreign exchange. Automatic financing of government deficits gave way to more independence for the Reserve Bank, but political pressures led to a uniquely Indian balancing between reducing inflation yet promoting growth. The distinctive feature of the study is it is not an official history like those currently available, but an independent academic work, that is closer to the international and to Indian academic literature, while it draws on the Indian experience largely from published materials, including official records.

\section{Structure}

The most important aspect of India's structure is the high population density, and the high proportion of the population in less productive occupations. The Hindu rate of growth (as Raj Krishna christened it) of below five per cent per annum, for much of the period, meant that even in 2010 average per capita was only about 1000 USD per capita and more than 70 per cent of the population remained in rural areas.

\section{II.1 Sectors}

Steady development had brought down the share of agriculture and allied activities in total income from 55 percent in 1950-51 to 30 pre reform and 15 in 2010; but since the population dependent on agriculture had not fallen commensurately, inequality increased. Poverty ratios had fallen with growth, and literacy had increased, but given the one billion plus population absolute numbers below the poverty line also remained at above 300 million, and illiteracy above 30 percent. The proportion of population in the most productive age group of 20-59 reached about 50 percent by 2010 . This implied a large expansion in the work force needing to be equipped with the appropriate skills ${ }^{2}$.

\footnotetext{
${ }^{2}$ The original source for the data processed in tables and charts, unless otherwise mentioned, is the RBI and the CSO. Data is often conveniently available on their websites.
} 


\begin{tabular}{|c|c|c|c|}
\hline At Constant Prices & Industry & Services & Agriculture \\
\hline $1950-51$ to $1959-60$ & 11.62 & 34.38 & 47.58 \\
\hline $1960-61$ to $1969-70$ & 15.02 & 39.14 & 40.41 \\
\hline $1970-71$ to $1979-80$ & 16.74 & 42.18 & 36.24 \\
\hline $1980-81$ to $1989-90$ & 18.66 & 46.3 & 31.97 \\
\hline $1990-91$ to $1999-00$ & 20.09 & 51.51 & 26.01 \\
\hline $2000-01$ to $2009-10$ & 19.69 & 60.29 & 18.23 \\
\hline
\end{tabular}

\begin{tabular}{|c|c|c|c|c|c|c|c|c|c|c|c|c|}
\hline $\begin{array}{l}\text { At } \\
\text { constant } \\
\text { prices } \\
(1999- \\
00=100)\end{array}$ & $\begin{array}{l}\text { GDP at } \\
\text { factor } \\
\text { cost }\end{array}$ & $\begin{array}{l}\text { Agricultur } \\
\text { e \& Allied } \\
\text { Activities }\end{array}$ & $\begin{array}{l}\text { Agricultur } \\
\text { e }\end{array}$ & Industry & $\begin{array}{l}\text { Mining \& } \\
\text { Quarryin } \\
\text { g }\end{array}$ & $\begin{array}{l}\text { Manufactu } \\
\text { ring }\end{array}$ & $\begin{array}{l}\text { Electricity, } \\
\text { Gas \& } \\
\text { Water } \\
\text { Supply } \\
\end{array}$ & Services & $\begin{array}{l}\text { Constructi } \\
\text { on }\end{array}$ & $\begin{array}{l}\text { Trade, } \\
\text { Hotels, } \\
\text { Transport \& } \\
\text { Communicati } \\
\text { on }\end{array}$ & $\begin{array}{l}\text { Financing, } \\
\text { Insurance, } \\
\text { Real Estate \& } \\
\text { Business } \\
\text { Services } \\
\end{array}$ & $\begin{array}{l}\text { Community, } \\
\text { Social \& } \\
\text { Personal } \\
\text { Services }\end{array}$ \\
\hline \multicolumn{13}{|c|}{ Average Annual Growth Rate } \\
\hline $\begin{array}{l}1951-52 \text { to } \\
1959-60 \\
1960-61 \text { to }\end{array}$ & 3.58 & 2.74 & 2.99 & 5.67 & 3.53 & 5.81 & 10.69 & 4.2 & 5.76 & 5.05 & 3.07 & 3.51 \\
\hline $\begin{array}{l}1969-70 \\
1970-71 \text { to }\end{array}$ & 3.95 & 2.51 & 2.52 & 6.21 & 6.19 & 5.88 & 11.43 & 5.19 & 7.18 & 5.37 & 3.21 & 5.23 \\
\hline $\begin{array}{l}1979-80 \\
1980-81 \text { to }\end{array}$ & 2.95 & 1.25 & 1.41 & 4.35 & 3.05 & 4.31 & 6.91 & 4.03 & 1.95 & 4.78 & 4.3 & 4.12 \\
\hline $\begin{array}{l}1989-90 \\
1990-91 \text { to }\end{array}$ & 5.58 & 4.41 & 4.67 & 6.36 & 8.71 & 5.77 & 8.49 & 6.29 & 4.83 & 5.97 & 8.67 & 5.9 \\
\hline $\begin{array}{l}1999-00 \\
2000-01 \text { to }\end{array}$ & 5.68 & 3.24 & 3.29 & 5.67 & 4.77 & 5.62 & 7.27 & 7.09 & 5.63 & 7.47 & 8.05 & 6.46 \\
\hline $2009-10$ & 7.2 & 2.42 & 2.53 & 7.45 & 5.02 & 8.12 & 5.67 & 8.82 & 9.13 & 9.98 & 9.38 & 6.15 \\
\hline
\end{tabular}

Table 1 gives the decadal averages, showing the changes in sectoral composition.

Over the years, the economy changed from being agriculture-dominant to servicesdominant. The share of industry doubled, but remained low at about 20 percent. Post reform higher growth was driven by various service sectors, industry also grew after 2000, but infrastructure, which had done better in the previous 2 decades slowed (Table 2). Agriculture had its best rate of growth in the eighties. 


\section{II.2 Growth and inflation}

Financial markets were quite active at the time of independence; interest rates were market determined; an incipient bill market was also developed. But according to the ideas of the time planning was extended to the monetary and financial system also. To support planned development, with the commanding heights for capital-intensive public sector projects, the emphasis was on generating resources for public investment, allocating resources to priority sectors, and expanding the reach of the formal financial system.

After a good initial start with the $1^{\text {st }}$ and $2^{\text {nd }}$ five-year plans, the system was unable to raise growth rates or moderate the supply-side shocks the economy was subject to.

Table 3 shows decadal average inflation rates were dominated by primary goods and fuel (FPLL) inflation. Liberalization, and the effect of competition from abroad, reduced primary good and manufacturing inflation in 2000 s, but the severe international food and oil price shocks pushed it up in the last years of the decade (Chart 1).

\begin{tabular}{llllllll}
\hline \multicolumn{7}{c}{ Table 3: Average Annual Inflation } \\
\hline $\begin{array}{l}\text { Base } \\
\mathbf{1 9 8 2}=100\end{array}$ & $\begin{array}{l}\text { WPI (All } \\
\text { Commodities) }\end{array}$ & $\begin{array}{l}\text { WPI } \\
\text { (Primary } \\
\text { Goods) }\end{array}$ & $\begin{array}{l}\text { WPI } \\
\text { (Food } \\
\text { Articles) }\end{array}$ & $\begin{array}{l}\text { WPI } \\
\text { (Non- } \\
\text { Food } \\
\text { Articles) }\end{array}$ & $\begin{array}{l}\text { WPI } \\
\text { (FPLL) }\end{array}$ & $\begin{array}{l}\text { WPI } \\
\text { (Manufacturing) }\end{array}$ & $\begin{array}{l}\text { CPI } \\
\text { (IW) }\end{array}$ \\
\hline $\begin{array}{l}1953-54 \text { to } \\
1959-60\end{array}$ & 2.47 & 2.94 & & 2.3 & 1.62 & \\
$\begin{array}{l}1960-61 \text { to } \\
1969-70\end{array}$ & 6.34 & 7.43 & & 5.03 & 4.92 & \\
$\begin{array}{l}1970-71 \text { to } \\
1979-80\end{array}$ & 8.97 & 8.95 & 7.23 & 8.56 & 12.15 & 9.03 & 9.32 \\
$\begin{array}{l}1980-81 \text { to } \\
1989-90\end{array}$ & 7.97 & 7.76 & 8.57 & 7.69 & 9.21 & 7.86 & 8.48 \\
$\begin{array}{l}1990-91 \text { to } \\
1999-00\end{array}$ & 8.12 & 9.37 & 10.24 & 8.31 & 10.56 & 7.13 & 8.73 \\
$\begin{array}{l}2000-01 \text { to } \\
2009-10\end{array}$ & 5.27 & 5.68 & 5.27 & 5.64 & 8.05 & 4.34 & 6.75 \\
\hline
\end{tabular}



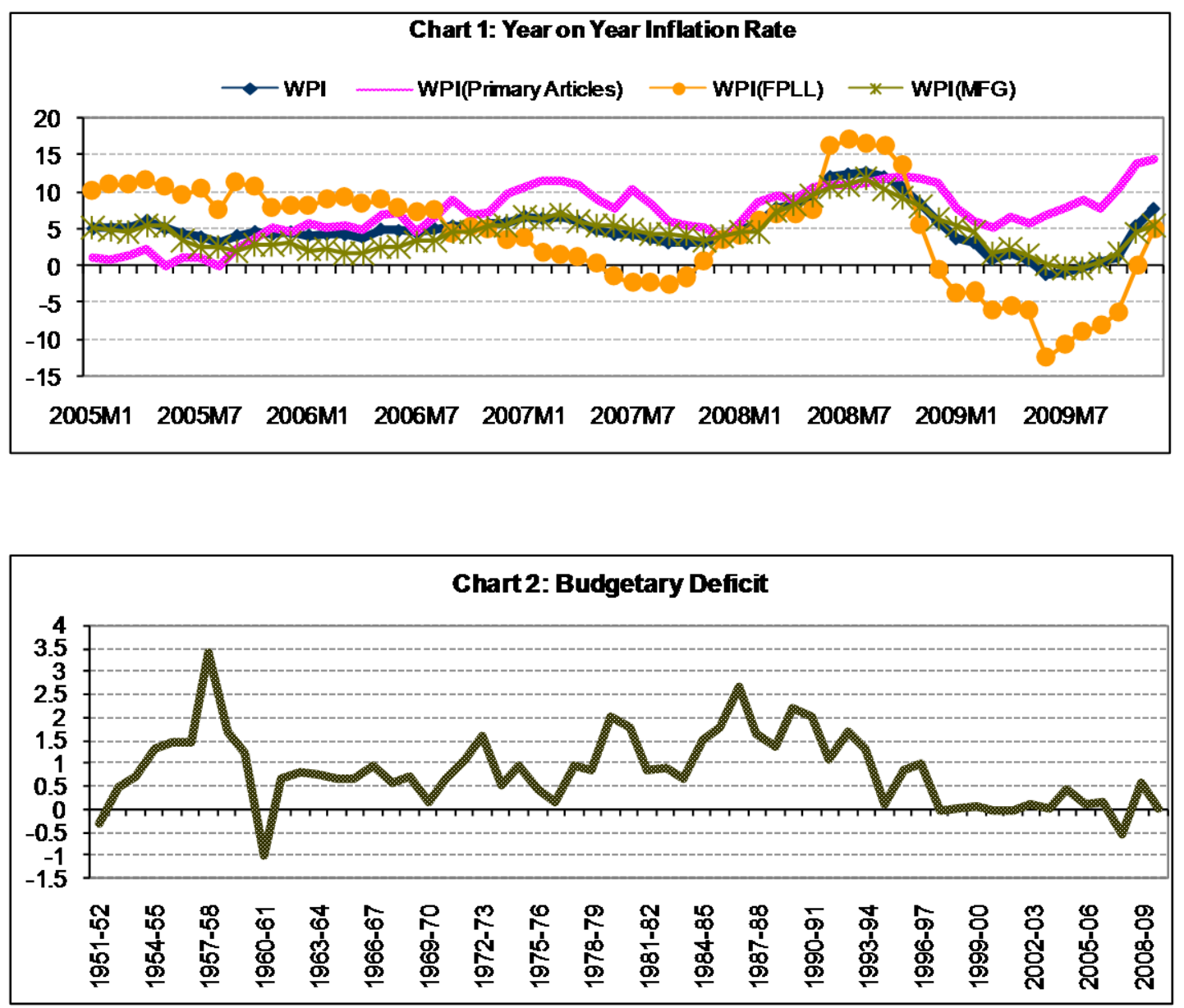

Ambitious projects in the second 5-year plan, and a paucity of resources, made the government soon turn to deficit financing (Chart 2). In these years the Reserve Bank of India (RBI) lost its initial independence (see Section IV), and its primary responsibility became to find resources the Government expenditure. It always had a commitment to developmental functions such as expanding credit to agriculture and other priority sectors. In addition, in a democracy with a large number of poor high inflation was not acceptable. Therefore tight control was kept on aggregate money supply, but selective credit controls were used to direct credit in line with Plan priorities (see Section V).

The push towards inclusive financial deepening, especially the expansion of bank branches after nationalization, probably contributed to the sharp rise in the savings (GDS) GDP ratio in the 70s. Another large jump came in the post-reform high growth period, and the growth rate of GDS overtook that of capital formation (GDCF) and consumption (PFCE) (Table 4). India has a healthy combination of savings to finance 
investment and consumption to create demand. But the savings are poorly intermediated through the financial sector, and even in 2010 less than half the population had a bank account.

\begin{tabular}{llll}
\hline \multicolumn{4}{c}{ Table 4: Savings, Investment and Consumption } \\
\hline At current Prices & GDCF & PFCE & GDS \\
\hline \multicolumn{4}{c}{ Average Annual Growth Rate } \\
\hline 1950-51 to 1959-60 & 8.06 & 5.17 & 8.67 \\
1960-61 to 1969-70 & 12.87 & 9.61 & 13.69 \\
1970-71 to 1979-80 & 15.15 & 10.46 & 15.28 \\
1980-81 to 1989-90 & 17.06 & 13.58 & 16.04 \\
1990-91 to 1999-00 & 16.09 & 14.34 & 16.62 \\
2000-01 to 2009-10 & 14.83 & 11.07 & 16.18 \\
\hline \multicolumn{5}{c}{ As a Percentage of GDP at Market Price } \\
\hline 1950-51 to 1959-60 & 11.30 & 90.58 & 9.85 \\
1960-61 to 1969-70 & 14.31 & 83.38 & 12.44 \\
1970-71 to 1979-80 & 17.88 & 77.64 & 17.88 \\
1980-81 to 1989-90 & 21.41 & 71.62 & 19.40 \\
1990-91 to 1999-00 & 24.56 & 64.30 & 23.24 \\
2000-01 to 2009-10 & 31.87 & 59.08 & 29.16 \\
\hline
\end{tabular}

\section{II.3 Politics}

A majoritarian democratic regime, such as India's, has a bias towards targeted transfers at the expense of public goods, compared to a regime based on proportional voting. Political fragmentation, after the first twenty years of independence when the Congress party provided a stable government, made matters worse. As the Congress lost dominance and intense multi party competition set in, populist schemes multiplied. With multiple competing parties, swing votes become critical for winning in a first-past-the-post system. After the oil shocks of the seventies, several user charges for public goods were kept fixed, although costs were rising. Subsidies, transfers and distortions increased while current and future provision of public goods suffered.

By the 1980s, populist Central Sponsored Schemes (CSS) became a way for the central government to directly reach the masses. New schemes were announced every year, although targeting was poor and waste and corruption proliferated. Since state elections were separated from those at the Centre in 1971, frequent elections kept this 
pressure up continually and harmed longer-term development. The first reaction of new caste-based parties to the acquisition of power was consumption transfers to their support groups, especially as belief in a vibrant future was missing since the development policies of the past had not delivered growth. Once in power they were concerned with "loot" in order to buy votes and legislators in the future. Institutions of governance were undermined. In the South where the caste-based movement was older, progressive reform, emphasizing education and capacity building, was achieved (Goyal, 2003).

The objective of providing government services at affordable prices led to crosssubsidization both in the provision of specific products and across government functions. Low price caps for many public goods led to systematic incentives to lower quality and investment. Thus falling efficiency and rising costs compounded the problem of low user charges, and prevented a natural fall in prices from improvements in technology and organization. But where the government had monopoly power and was servicing the rich, prices were raised much above costs of production, or indirect charges, not obvious to voters, such as the prices of intermediate goods, were raised. As the rich turned to private providers, revenue losses contributed to the inability to service the poor adequately. The crosssubsidization was not sufficient to cover costs. The choices made amounted to protecting the poor through current transfers, rather than building their assets and human capital, when it was the latter that was the sustainable option. This was a rational social outcome because the rich could often escape imposts in the long-term, and the poor had high discount rates and pessimistic growth projections.

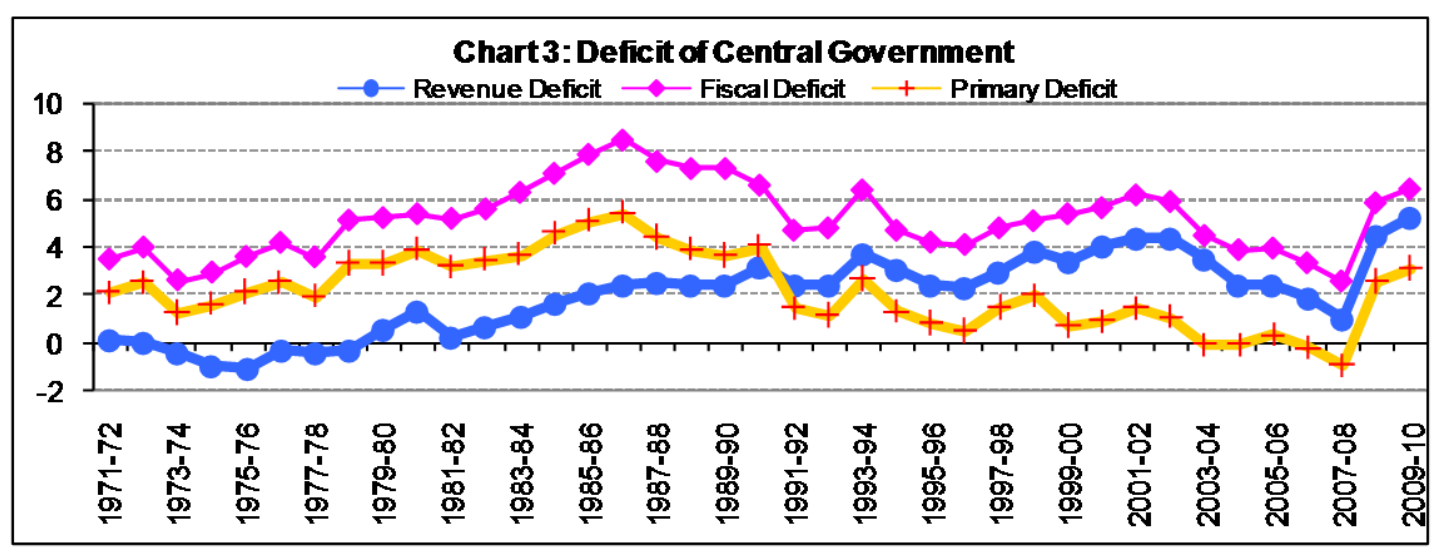




\section{II.4 Government finances}

As these effects cumulated, the revenue deficit became positive. That is, government consumption exceeded its income. Chart 3 , shows that the first year the revenue deficit became positive was 1980-81 and there was never a surplus on current account after that. This is the amount the government needs to borrow to finance its own consumption. The government's borrowing in any year to finance current and capital expenditure net of tax and non-tax revenue is its fiscal deficit. The primary deficit is the fiscal deficit minus interest payments. Since this is net of the burden of servicing debts due to past borrowing it is a measure of current borrowing, and of fresh addition to government debt. This, along with interest payments, adds to government debt. Chart 3 shows the fiscal and primary deficits began to fall after the reforms. The primary deficit even became briefly negative, but given the burden of interest payments on past debt, the revenue deficit could not fall until interest rates fell and tax buoyancy was established in 2003. All three deficits shot up again with the fiscal stimulus after the global financial crisis.

In the early years the only deficit concept used was that of budget deficit (Chart 2). This was the change in outstanding treasury bills ( $\mathrm{T}$ bills), Government deposits and other cash balances with the RBI. The budget deficit underestimated the monetary impact of the deficit since it did not include RBI holdings of dated Government securities (Gsecs). The RBI largely held the treasury bills. To the extent they were held by banks their monetary impact was reduced. RBI credit to the government gives the correct monetary impact of fiscal operations. After 1996, when automatic monetization of the deficit was reduced, and government funding by banks increased, the budget deficit falls (Chart 2).

As fund constraints appeared, it was easiest to postpone investment plans. This strategy continued in the post-reform period. Table 5 shows the trend reduction in capital expenditure compared to revenue expenditure, and the sharp fall in capital expenditure in the post reform period. This allowed some improvement in the fiscal and primary deficit that was specially marked after 2000 (Table 6), a period of tax buoyancy from reform and higher growth. Fiscal responsibility legislation also contributed, but was overturned by the global crisis. The revenue deficit, however, remained high as well-entrenched populist expenditures became difficult to cut. There 
was an argument that some expenditures essential to build human capacity were classified as current not capital expenditure. The government accumulated debt both since it was borrowing for consumption, it was earning very low returns on its investments, and its expenditures were not successful for a long time in improving growth and taxes. Expenditures once implemented set in self-sustaining dynamics partly by creating interest groups or constituencies they favoured.

\begin{tabular}{|c|c|c|c|c|c|c|}
\hline \multicolumn{7}{|c|}{ Table 5: Center's Fiscal Position } \\
\hline \multicolumn{7}{|c|}{ (As a percentage of GDP at Current Market Price) } \\
\hline & $\begin{array}{l}\text { Revenue } \\
\text { Receipt }\end{array}$ & $\begin{array}{l}\text { Tax } \\
\text { Revenue }\end{array}$ & $\begin{array}{l}\text { Non Tax } \\
\text { Revenue }\end{array}$ & $\begin{array}{l}\text { Total } \\
\text { Expenditure }\end{array}$ & $\begin{array}{l}\text { Revenue } \\
\text { Expenditure }\end{array}$ & $\begin{array}{l}\text { Capital } \\
\text { Expenditure }\end{array}$ \\
\hline $1950-51$ to $1959-60$ & - & 4.5 & - & 7.14 & 3.75 & 3.39 \\
\hline $1960-61$ to $1969-70$ & - & 6.7 & - & 12.32 & 5.87 & 6.46 \\
\hline $1970-71$ to $1979-80$ & 1067 & 8.69 & 2.2 & 14.62 & 8.62 & 6 \\
\hline $1980-81$ to $1989-90$ & 12.56 & 9.96 & 2.7 & 17.84 & 11.68 & 6.16 \\
\hline $1990-91$ to $1999-00$ & 12.21 & 9.19 & 2.93 & 15.7 & 12.28 & 3.41 \\
\hline $2000-01$ to $2009-10$ & 12.9 & 10.01 & 2.99 & 15.4 & 12.97 & 2.49 \\
\hline \multicolumn{7}{|c|}{ Decadal Growth Rate } \\
\hline $1950-51$ to $1959-60$ & & 8.5 & & 14.55 & 9.06 & 24.91 \\
\hline $1960-61$ to $1969-70$ & & 13.72 & & 13.52 & 15.22 & 12.34 \\
\hline $1970-71$ to $1979-80$ & 15.44 & 15.6 & 14.4 & 14.25 & 16.25 & 12.14 \\
\hline $1980-81$ to $1989-90$ & 16.41 & 15.79 & 19.41 & 17.31 & 18.56 & 15.05 \\
\hline $1990-91$ to $1999-00$ & 13.85 & 12.98 & 17.18 & 12.43 & 14.53 & 6.37 \\
\hline $2000-01$ to $2009-10$ & 13.06 & 14.47 & 10.2 & 13.29 & 14.01 & 13.06 \\
\hline
\end{tabular}

\begin{tabular}{llll}
\hline \multicolumn{4}{c}{ Table 6: Deficit of Central Government (Averages) } \\
\hline \multicolumn{4}{c}{ (As a Percentage of GDP at Current Market Price) } \\
\hline & Revenue deficit & Fiscal deficit & Primary Deficit \\
\hline $\begin{array}{l}1970-71 \text { to } \\
1979-80\end{array}$ & -0.12 & 3.9 & 2.4 \\
$\begin{array}{l}1980-81 \text { to } \\
1989-90\end{array}$ & 1.9 & 6.8 & 4.1 \\
$\begin{array}{l}1990-91 \text { to } \\
1999-00\end{array}$ & 3.1 & 5.1 & 1.6 \\
$\begin{array}{l}2000-01 \text { to } \\
2009-10\end{array}$ & 3.34 & 4.8 & 0.8 \\
\hline
\end{tabular}

In the more recent period, as growth creates more opportunities for the people, delivery and governance have begun to matter for electoral performance. Even as 
monetary policy got some degrees of freedom from fiscal and legislative improvements, large inflows after reforms created new constraints. After this brief review of the structure within which monetary policy had to operate, we turn to the ideas that influenced policy.

\section{III.Ideas}

India may have become a closed economy for much of the period, but it has always been quite open to global academic ideas. The dialectic between these and structure, needs, and the domestic political and economic debate affected policies followed.

\section{III.1 Keynes modified}

The 50s were the period when Keynesian ideas dominated. Especially following the Great Depression, Government expenditure was thought to be the dominant macroeconomic tool. But the Indian debate was more nuanced. VKRV Rao (1952) argued that pervasive supply bottlenecks could be expected to make demand stimuli ineffective in a country like India. It was Government investment that was to take the lead in reliving supply bottlenecks through the Plan expenditures. Financing these expenditures was an obvious concern. Indian policy followed Keynesian ideas in giving government expenditure pride of place, with monetary policy to support it. But the expenditure was to expand supply rather than create demand. Policy was also Keynesian in giving priority to quantity adjustment and intervention over price. Monetarists tended to favour the use of markets with the role of the government restricted to creating an enabling environment for the private sector; Keynesians were more interventionist—favouring discretionary monetary and fiscal policies.

From the beginning RBI was committed to development. In the context of large planned expenditure it was natural to emphasize credit and its allocation to productive uses. But ensuring credit availability for the Government and priority sectors, while meeting aggregate targets, meant restricting credit to other sectors. In the beginning interest rates were market determined, but market allocation was discounted in favour of rationing quantities. Among recommendations of the influential UK Radcliffe committee (1958), which provided support for these policies, were that government debt and market liquidity management should be the focus of monetary policy; and too large interest rate variations disturb markets. A variety of devices were used to 
intervene in credit allocation. Apart from general credit guidelines to direct bank credit to priority sectors; selective credit controls were used, for example, to limit advances against certain commodities to mitigate speculative hoarding. But at the same time banks were forced to finance the large credit needs of the government food procurement and distribution system.

Following the USSR model and the ideas of Mahalanobis the plans favoured a big push to develop indigenous heavy industry. Vakil and Brahmananda (1956) pointed out early that in an economy like India, the critical constraint was likely to be wage goods, requiring focus on agriculture. They noted that whereas in a developed country the rate of growth of capital equals that of population, and gives its rate of growth, in an underdeveloped country the potential workforce exceeds capital stock. Development, that raises per capita incomes, must involve a period where the rate of growth exceeds that of population; the constraint that prevents this, and sustains underemployment, is the supply of wage goods. Structural rigidities did influence early thinking at the RBI (Pendharkar and Narasimham 1966), but it led to quantitative credit allocation over the use of general interest rate instruments in order to encourage development activity and lower the cost of Government borrowing. A satisfactory combination of key monetary and structural features has proved elusive in Indian Keynesian-Structuralist or Monetarist models ${ }^{3}$.

The inward-looking import-substituting approach led to a severe foreign exchange constraint. The foreign exchange regulation act 1974 was used to implement severe rationing of foreign exchange, with heavy regulation of markets. Neglect of the wage goods constraint in planning exercises meant inflation soon surfaced. But the response to this was monetary. The acceptance of the economy as supply and not demand constrained, together with the political sensitivity to inflation, meant restriction on aggregate money supply growth was regarded as the answer to inflation. It was also regarded as the answer to widening government deficits. Increasing the statutory liquidity and compulsory reserve ratios of commercial banks both financed government spending and restricted aggregate money supply growth even as reserve bank credit to the government continued to increase.

\footnotetext{
${ }^{3}$ Krishnamurthy and Pandit (2005), Rakshit (2009), and Balakrishnan (1994) are fine examples of structuralist thinking in the Indian context. Jadhav (1990) surveys monetary models.
} 


\section{III.2 Monetarism in the aggregate}

If money, following Keynes, was regarded as having limited impact on the real sector because of the liquidity trap and low demand elasticities, the quantity theory of money linking the money supply to the price level was largely accepted as the analytical framework underpinning the supply of money ${ }^{4}$. Given reasonable predictability of money demand and the money multiplier, monetary targeting was feasible if reserve money could be controlled. Rising income elasticity of money demand could be factored in. Given automatic financing of the budget deficit, raising the reserve ratios was a way to control reserve money.

Estimations largely gave a stable money demand ${ }^{5}$, when enhanced to include variables relevant in the Indian context, such as relative shares of agriculture and nonagricultural output and the degree of monetization ${ }^{6}$. Interest elasticity was low $^{7}$, and income elasticity of demand for broad money was about 1.5 to 2 (Gupta 1972, 1976, Vasudevan, 1977). On the supply side, the money multiplier (that multiplied the reserve money to generate the money stock) was also stable. So it was thought possible to derive an acceptable rate of growth of money supply by adjusting the growth of reserve money by changes in the reserve ratio. For money supply to be used to determine prices the first step is for the RBI to be able to control money supply.

The money multiplier shows how broad money (M) can be created as a multiple of base or high-powered money $(\mathrm{H})$ given the currency deposit $(\mathrm{C} / \mathrm{D})$ and bank reserves to deposit ratio (R/D). The multiplier decreases with both, since both decrease the

\footnotetext{
${ }^{4}$ In Irving Fisher's version the quantity theory of money is written as MV=PY. With constant velocity (V) and output (Y) at full employment, there is a one-to-one relation of money supply (M) and the price level (P). Velocity would change with the factors affecting the demand for money such as income and the nominal interest rate. But predictable or stable changes in money demand could be factored in to arrive at money supply targets.

${ }^{5}$ As late as 1995, Rao and Singh argued that in spite of the overwhelming international evidence on instability of money demand, Indian money, income and a relevant interest rate were cointegrated, demonstrating long-run stability. Even so, their view was that targeting of nominal income, or velocity, is superior to targeting some monetary aggregate, since velocity can be derived independently or residually, without trying to invert a questionable money demand schedule.

${ }^{6}$ Brahmananda's (2001) monetary history was based on the quantity theory of money following Friedman and Schwartz's (1971) famous US history, but he modified it to suit $19^{\text {th }}$ century India, for example, by including an index of rainfall as a determinant of the price level, and an index of monetization as a determinant of velocity.

${ }^{7}$ This was not surprising given that markets were suppressed. Pre-independence studies had found significant interest elasticities (Anjaneyulu et. al. 2010).
} 
credit banks can generate from a given base ${ }^{8}$. In the seventies the RBI followed a balance sheet approach for determining the components of money supply. This assumed the money multiplier to be constant even in incremental terms. But $\mathrm{C} / \mathrm{D}$ can be expected to fall, for example, as bank branches rise. An adjusted multiplier corrects for changes in cash reserves.

A number of authors sought to obtain more accurate predictions of the money multiplier and improve the analytical understanding of money supply determination (Gupta1976, Singh et. al. 1982, Rangarajan and Singh, 1984). Forecasting exercises included Rao, Venkatachalam and Vasudevan 1981, Chitre 1986, Nachane and Ray, 1989. The studies were an important policy input. To target the money stock from a given base or highpowered money, it was necessary to predict the money multiplier, so that bank's contribution to raising money supply could be quantified.

But macroeconomic variables are determined in a complex interactive process. The studies did not adequately analyze the interactions between the players who determine money supply. They ignored feedback, simultaneous equation bias and identification problems. Even in 1959 banks found legitimate ways to expand credit to meet rising demand despite higher reserve requirements. They reduced cash in hand and excess balances with the RBI, sold Gsecs (dated government securities), maintained large outstandings on RBI accommodation, thus liquidating investments rather than reducing advances as they were expected to. The RBI's response was to make access to its financing temporary to try and close loopholes (Balachandran, 1998 pp.79-80).

If banks managed some autonomy to maximize profits even in a regime of direct credit controls, then these strategies can be expected to dominate in a liberalized era. Money demand will become unstable as close financial substitutes develop. Although loans create deposits, loans are determined both by supply and demand. They depend on profit maximization by banks, and on RBI monetary policy that changes base money.

\footnotetext{
${ }^{8} \mathrm{M}=\mathrm{mH}$, where $\mathrm{m}$ is derived from the two identities $\mathrm{M}=\mathrm{C}+\mathrm{D}$ and $\mathrm{H}=\mathrm{C}+\mathrm{R}$ by dividing the first from the second, and then dividing the numerator and denominator by $1 / \mathrm{D}$ to get $\mathrm{M}=((1+\mathrm{C} / \mathrm{D}) /(\mathrm{R} / \mathrm{D}+\mathrm{C} / \mathrm{D}))$ $\mathrm{H}$ (Goodhart 2007). The multiplier can also be written as $\mathrm{m}=[(\mathrm{D} / \mathrm{R})(1+\mathrm{D} / \mathrm{C}) /(\mathrm{D} / \mathrm{R}+\mathrm{D} / \mathrm{C})]$ by multiplying the right side by $[(\mathrm{D} / \mathrm{CR}) /(\mathrm{D} / \mathrm{CR})]$. The multiplier reduces when $(\mathrm{D} / \mathrm{R})$ or $(\mathrm{D} / \mathrm{C})$ falls.
} 
Dash and Goyal (2000) found money supply to be neither fully endogenous, nor fully controlled in a new specification employed to test for the degree of endogeneity of commercial bank credit, and its response to structural variables relevant to the Indian context. They used the variable $\mathrm{M}-\mathrm{H}$ to identify money supply in a single equation, and disentangle the contribution of the Central and the Commercial banks to the money supply process over 1960-61 to 1992-93. They found bank credit reacted more to financial variables and had dissimilar responses to food and manufacturing prices and output. Credit turned out to be the endogenous outcome of incentives facing agents. But in the data set, as interest rates were imperfectly flexible, a range of price variables carried these incentives. Whenever incentives to expand credit were high enough, banks found ways around a variety of quantitative controls. They suggested price bubbles in assets that lead to expansions in broad money could be better controlled through taxbased regulation.

Although the RBI was able to affect base money, banks were able to circumvent controls and expand credit when there were profits to be made. Money supply had been somewhat exogenous, but fundamental changes were occurring that made it more endogenous.

\section{III.3 Globalization: Ideas and domestic impact}

Liberalization and deepening financial markets made monetary policy more effective and faster so that its use dominated macro stabilization from the 1980s. In the seventies the developed world moved to the float as the dollar was delinked from gold, and gradually began to open capital accounts.

Ricardian equivalence type arguments suggested private actions would counter fiscal policy. For example, if government spent more, taxpayers foreseeing a rise in future taxes would save more. This would reduce the effect of government spending on demand. Long lags and political constraints on fiscal policy were also being recognized as weakening fiscal policy (Blanchard et. al. 2010). Markets were dominating governments and price adjustments were dominating quantity adjustments, once again. The instruments Central Banks (CBs) were using worldwide were interest rates. The classical neutrality of money doctrine held that real interest rates were determined by productivity and invariant to policy. Sargeant showed that 
an interest rate instrument could make the system unstable. But these results were shown to hold only if money was the only nominal standard. Sticky wages and prices create an alternative that fixes nominal variables, and allow real interest rates to be influenced by policy for considerable periods. Moreover, an interest rate rule that responded to macroeconomic variables such as output and inflation gaps would be stable (Goodhart, 2007).

As globalization and financial innovations occur, significant interest rate effects on domestic expenditures can be expected. Deeper financial markets spread effects more widely. Interest rates play a larger role in the transmission of monetary policy, and become the natural instrument of monetary policy, although other channels of transmission, such as credit, continue to be important. First, interest rates become more flexible and responsive to $\mathrm{CB}$ intervention; second, the interest rate becomes a more sensitive and fast signal of potential imbalances; third, demand for broad money becomes unstable and enhancement in its supply from commercial banks more flexible, so that targeting monetary aggregates becomes difficult, and the attempt causes high volatility in interest rates; and fourth, the size of foreign exchange, bond, equity and other asset markets rises. These markets are very sensitive to interest rates. Now forward-looking behavior becomes more important and markets try to guess the CB's response to uncertainty and to shocks. Thus, transparency becomes a major issue. As markets develop, the reason most CB's start targeting interest rates is it becomes necessary for market stability. A fractional banking system and leveraged financial sector must have funds available whenever required in order to function. It is necessary for the operation of interbank markets.

In India, however, the entire interest rate structure was still administered, and markets underdeveloped as quantity rationing was in force, so estimated interest elasticities of aggregate and money demand were low. There was an argument that interest elasticity would be low in India given the dualistic structure and limited reach of the modern financial sector (Rakshit 2009). But the deleterious effects of quantitative controls were beginning to be recognized. The perception that India was stuck at a low one percent per capita growth while countries that had opened out in the $60 \mathrm{~s}$, such as South Korea, were doing much better was becoming common. The Chakravarty Committee (RBI, 1984) set up to review the working of the monetary system wrote: 
“...there does appear to be a strong case for greater reliance on the interest rate instrument with a view to promoting the effective use of credit, and in short-term monetary management. Over the years quantitative controls on credit have increasingly borne the major burden of adjustment required under anti-inflationary policies and have in the process given rise to distortions in credit allocations at the micro level (pp. 161-2).”

Although it opted for an overall monetary targeting approach the committee did warn that in an economy such as India with structural rigidities, supply shocks and structural changes, a monetary growth rate must not be mechanically implemented, but should be seen rather as an indicative, flexible, target range. It suggested a range around 14 percent for broad money growth, based on an average output growth of 5 percent, inflation at 4 percent, and income elasticity of broad money demand of 2 .

It suggested a greater role for the interest rate in influencing the demand for credit, thus reducing the sole reliance on rationing the supply of credit, and allowing more productive credit allocation ${ }^{9}$. It advocated more market holding of treasury bills (for short term finance) and Gsecs. A retail market for Gsecs was also to be encouraged. These alternative avenues for government borrowing were expected to give the RBI greater freedom to use open market operations (OMOs), or sale and purchase of Gsecs both outright and repos, to control reserve money. As interest rates rose a fall in capital value would militate against higher voluntary holdings, so it was suggested the valuation of Gsecs held to satisfy SLR be based on purchase price and not on market value.

Narasimham Committee (RBI, 1991) echoed these concerns, as did the working group on the money market (RBI, 1987).

"The committee is of the view that the SLR instrument should be deployed in conformity with the original intention of regarding it as a prudential requirement and

\footnotetext{
${ }^{9}$ Even banks used a system of cash credit rather than bills and loans to finance working capital, which reduced their supervision of the end use of credit.
} 
not be viewed as a major instrument for financing the public sector (RBI, 1991, pp.iv)" and the next recommendation on pp. v "..proposes that the Reserve Bank consider progressively reducing the cash reserve ratio from its present high level. With the deregulation of interest rates there would be more scope for the use of open market operations by the Reserve Bank with correspondingly less emphasis on variations in the cash reserve ratio."

Low returns from deficit financed public investment and growth stagnation in a protected economy contributed to worsening deficits, and accumulating debt. This faltering of fiscal policy in India was bolstered by international changes in dominant ideas.

While the original Keynesian position had been that fiscal policy was generally more effective than monetary policy; the New Keynesian view was that interest rates were effective in closing the output gap, given wage-price rigidities, except in extreme liquidity traps. Even the original Monetarist position was misunderstood. Friedman's famous quote about money being a veil and having no effect on the real sector has an important rider:

"Money is a veil. The "real" forces are the capabilities of the people, their industry and ingenuity, the resources they command, their mode of economic and political organization, and the like (Friedman and Schwartz, 1971, pp 606)....Perfectly true. Yet also somewhat misleading, unless we recognize that there is hardly a contrivance man possesses which can do more damage to society when it goes amiss (pp 607)." This was to be expected from a monetary history that covered the Great Depression.

They also identified the fundamental reasons that create problems from both too tight and too loose monetary policies. Too tight policies can destroy the financial system since:

"Each bank thinks it can determine how much of its assets it can hold in the form of currency, plus deposits at the Federal Reserve Banks, to meet legal reserve requirements and for precautionary purposes. Yet the total amount available for all banks to hold is outside the control of all banks together (pp 607)." 
But too loose can destroy confidence in the currency:

“...that common and widely accepted medium of exchange is, at bottom, a social convention which owes its very existence to the mutual acceptance of what from one point of view is a fiction".

The monetary squeeze was particularly tight in India after the oil shocks of the seventies and had a high output cost. But a better synthesis of Keynesian and Monetarist ideas was becoming feasible.

\section{III.4 New Keynesian theories in emerging markets}

The New Keynesian school (Clarida et.al 1999, 2001, Woodford 2003) demonstrates how monetary policy can work effectively through an interest rate instrument that reacts to expected inflation. Results are based on simple IS (investment equals savings) curve and Phillips curve (PC), derived from rigorous optimization by agents with foresight. They differ from standard formulations in the strong theoretical foundations, which make them robust to policy shocks ${ }^{10}$, and give them forwardlooking behaviour. The IS curve relates the output gap, or excess demand, inversely to the real interest rate, positively to expected future demand and to a positive demand shock. The PC curve relates inflation positively to the output gap, to future expected inflation and a cost-push or supply shock. The output gap is defined as the gap between actual and potential output. The PC relates inflation to the output gap rather than unemployment, and to cost-push. This, and the explicit modeling of relevant rigidities and distortions, makes it relevant to Indian conditions. Even though it is difficult to measure unemployment, the output gap can be defined for India. The idea of potential output and expected future changes in it are useful for an economy undertaking structural reform. Second, cost-push factors play a dominant role in inflation (Goyal, 2002).

Such a PC is derived assuming a certain probability that administered and other prices will remain fixed in any period. When a price is varied, it is set as a function of the expected future marginal cost. A proportionate relationship is assumed between the output gap and marginal cost. A cost shock, then, is anything that disturbs this

\footnotetext{
${ }^{10}$ Lucas had critiqued early Keynesian models. Since they were not derived from individual behaviour parameters could change with policy shocks, making them unreliable for the analysis of policy.
} 
relationship. Such deviations can occur due to administered prices, wage expectations, mark-up, exchange rate shocks, infrastructure bottlenecks and rising transaction costs in an emerging market. Some of these shocks affect average rather than marginal costs since they are independent of activity at the margin. For example, hiring more labour does not affect an administered price, but costs rise at all levels of activity when the price rises. Since an administered price increase is seldom reversed it raises future costs and is factored into the pricing of sticky-price goods today.

When cost-push is zero only current and future demand causes inflation. The CB can then vary interest rates to set excess demand to zero for all time and lower inflation with no cost in terms of output, which remains at its potential. A fall in output is required to lower inflation only if cost-push is positive. So a short-run trade-off between inflation and output variability arises only if there is positive cost-push inflation.

In mature economies, the modern macroeconomic approach focuses on employment. In this class of models labour is the key output driver (Woodford, 2003). Capital is a produced means of production. In an open economy resource bottlenecks are easier to alleviate. But even while following that approach, in emerging markets (EMs), the large informal sector is relegated to development economics. But once a populous EM crosses a critical threshold and high catch-up growth is established, higher labour mobility blurs the distinction between formal and informal sectors. A macroeconomics of the aggregate economy becomes both necessary and feasible. In labour-surplus economies established on a catch-up growth path, capital is available to equip labour and raise its productivity. Savings rise with growth and capital flows in with greater openness.

So the longer-run aggregate supply (LAS) or PC is elastic (Figure 1). But inefficiencies, distortions and cost shocks push aggregate supply upwards, over an entire range, rather than only at full employment, since that is not reached at current output ranges and output can increase. The LAS becomes vertical only as the economy matures and full productive employment is reached. With such a structure, demand has a greater impact on output and supply on inflation. This is the sense in which the economy is supply constrained (Goyal, 2011a, 2012). This framework 
differs from the early idea that output cannot be demand determined in a developing economy because of supply bottlenecks (Rao, 1952). Here output is demand determined but the supply-side raises costs. It also differs from the structural school that while industrial output is demand determined agricultural output is fixed at a time period. The difference arises because in an open economy supply bottlenecks are easier to alleviate. Even agricultural commodities can be imported, and the share of agriculture shrinks.

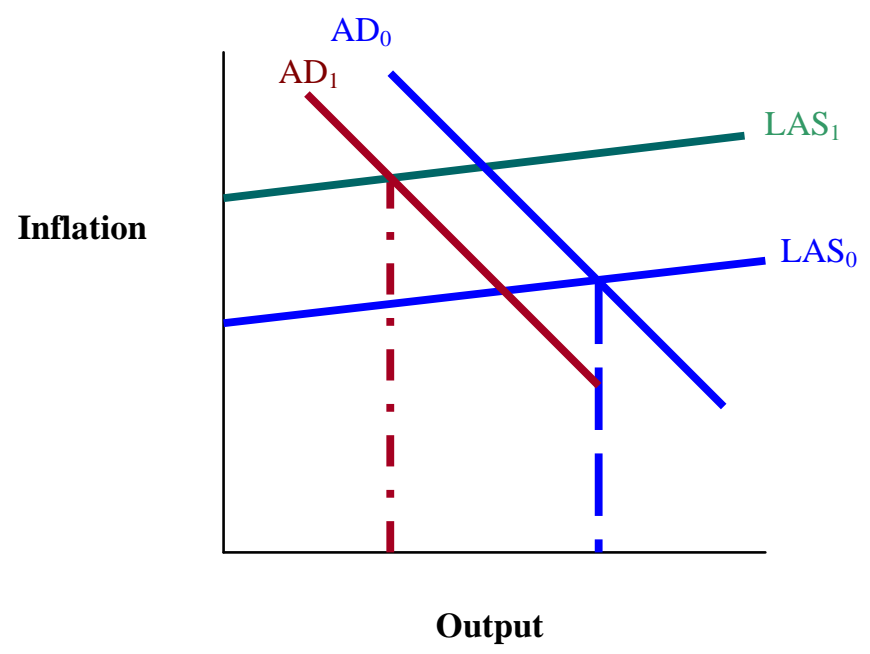

Figure 1: Aggregate demand and supply

Even so, the food price wage cycle is an important mechanism propagating price shocks and creating inflationary expectations in India, given low per capita incomes, and the large share of food in the consumption basket. If markets are perfectly clearing and prices and wages are flexible, then a fall in one price balances a rise in another with no effect on the aggregate price level. But prices and wages rise more easily than they fall. So, a rise in a critical price raises wages and therefore other prices, generating inflation. Some relative prices, among them food prices and the exchange rate, have more of such an impact. Food prices are critical for inflation in India and, since international food inflation now influences domestic, the exchange rate becomes relevant.

Political pressures from farmers push up farm support prices, with consumption subsidies also going up. But these are inadequate due to corruption and failures of targeting, so nominal wages rise with a lag pushing up costs and generating second round inflation from a temporary supply shock. This political economy indexes wages 
informally to food price inflation. Political support also raises wages through minimum wages and employment schemes such as MGNREGA. If the rise in subsistence wages exceeds that in agricultural productivity, prices in turn rise, propagating inflation. This happened after 2008 with MGNREGA as States competed with each other in raising minimum wages since the Centre was footing the bill. Given an exit option, workers' could extract large jumps in wages. Other types of populist policies that gave short-term subsidies but raised hidden or indirect costs also contributed to cost-push. For example, neglected infrastructure and poor public services increase costs.

Rigorous empirical tests based on structural vector autoregression (VAR), time series causality, Generalized Method of Moments (GMM) regressions of aggregate demand (AD) and aggregate supply (AS), and calibrations in a Dynamic Stochastic General Equilibrium (DSGE) model for the Indian economy support the elastic longer-run supply and the dominance of supply shocks (Goyal 2011b, 2008a, 2005). The sustained food inflation since 2008 led to some analysis of supply side factors (Gokarn, 2011; Mohanty, 2010). Joshi and Little (1994) have long argued that supplyside responses have been neglected in Indian macroeconomic policy.

Under a positive cost shock, forcing an immediate reduction in inflation would have a cost in terms of output foregone, which is especially high with the above structure of $\mathrm{AD}$ and $\mathrm{AS}$. Even with these structural inflation drivers monetary accommodation is required to sustain inflation and inflation expectations. But, with such a structure, even if some type of inflation targeting was to be considered, only flexible inflation forecast targeting with a positive weight to output stabilization maybe applicable.

To be able to apply inflation forecast targeting the CB has to first establish that it is able to forecast inflation. In an EM, a monetary conditions' index can be a precursor or complement to more formal inflation forecasting. It is a weighted set of variables that affect aggregate demand. The set and weights vary across countries but include money and credit aggregates, short-term interest rates, exchange rates and their fluctuations, direct measures of domestic inflation, commodity prices, wages and even some real variables such as capacity utilization. India moved to such a regime in 1998. 
Greater model uncertainty, and more backward-looking behaviour in EMs leads to making less than full use of forward-looking behavior in designing policy, in order to collect more information as well as lower asset-price volatility. The short-term interest rate mainly affects capital flows, exchange rates, and other asset prices. It is the longer-term interest rates that affect aggregate demand. Smoothing short-term interest rates can lower volatility in asset prices and yet allow the CB to directly affect demand through the long-term rate. If the short-term interest rate is expected to rise in the future, for example, the long-term rate will rise even more. So the long-term rate can be affected with a smaller current change in the short-term rate. But markets need to be surprised sometimes to prevent over-leverage and excessive risk-taking.

With flexible inflation forecast or zone targeting, sharp changes in interest rates are not required. It allows the discovery of potential output. In an EM, there is a high degree of uncertainty attached to the latter, and it changes more as reforms raise efficiency. With a flexible target, changes in potential output reveal themselves. If inflation does not rise even as output exceeds the expected potential, the potential must have risen. Focusing on core inflation allows the first round effects of supply shocks to be excluded from the target. Escape clauses can be built in for very large supply shocks. Core inflation exempts volatile prices such as food and oil, and therefore captures persistent demand driven inflation the CB can affect. However, headline inflation impacts the consumer, and if it becomes persistent, it cannot be ignored.

In a small open economy, monetary policy transmission depends also on the exchange rate channel. The lag from the exchange rate to consumer prices is the shortest (Svensson, 2000), especially if commodities dominate imports. In a typical EM, the effect of the exchange rate on inflation and capital flows and its role as an asset-price dominate. In these circumstances, varying the nominal exchange rate in a target band around the real exchange rate can make it feasible to smooth the nominal interest rate instrument and achieve the desired intermediate target real interest rate. If two-way movement of the nominal exchange rate is synchronized with temporary supply shocks, and the exchange rate appreciates with a negative supply shock, food and intermediate goods prices fall. This serves to pre-empt the effect of temporary supply 
shocks on the domestic price-wage process ${ }^{11}$. Building in a rule whereby there is an automatic announced response to an expected supply shock avoids the tendency to do nothing until it becomes necessary to over-react. Actions linked to exogenous shocks avoid moral hazard. Two-way movement of the exchange rate also encourages hedging thus reducing risk and developing foreign exchange markets. It also keeps the real exchange rate near equilibrium values preventing large and distorting deviation from fundamentals. There is evidence that while currency crises adversely affect trade, limited fluctuation in exchange rates do not have a large effect on trade. If limited volatility helps prevent crises and lower interest rates, it may even benefit trade.

Thus forward-looking monetary policy can use its knowledge of structure to abort the inflationary process. During a catch-up period of rapid productivity growth potential output exceeds output. As supply shocks are the dominant source of inflation, optimal policy should aim to achieve an inflation target only over the medium-term by which time temporary supply shocks have petered out, or been countered by exchange rate policy, changes in tax rates, or improvement in efficiencies. Flexible inflation targeting itself will prevent the inflationary wage-price expectations from setting in that can imply a permanent upward shift in the supply curve from a temporary supply shock. Monetary policy has to tighten only if there is excess demand.

In the international experience inflation targeting has been combined with an independent $\mathrm{CB}$. Is this a pre-requisite in India?

\section{Institutions}

In a democracy CBs are responsible for monetary and financial stability, but the government is subject to the pressures of election. Therefore the latter often forces the $\mathrm{CB}$ to try to raise output and employment. Once workers have made their work decisions based on expected wages, if the $\mathrm{CB}$ creates surprise inflation, this lowers real wages and unemployment since firms are then willing to employ larger numbers. Workers are tricked into working for lower wages. But over time such behaviour becomes anticipated, and higher nominal wages adjustments are built in, so there is

\footnotetext{
${ }^{11}$ In typical closed economy structuralist models agricultural markets were price clearing with quantities given, while quantities adjusted in non-agricultural markets. Therefore money supply could affect food prices. But in an open economy, agricultural supplies are not fixed even in the short period since imports are possible (Goyal 2004). Now the exchange rate affects food prices (Goyal 2010).
} 
only excess inflation, with no decrease in unemployment. This is known as the inflation bias, and a large literature has developed on it, which explores the structure of institutions, such as independence of a CB or appointment of a conservative central banker that can allow the $\mathrm{CB}$ to resist potential pressure. Bureaucrats are expected to be able to take a longer view compared to politicians since their reputation is their prime objective, not winning elections.

But in a poor populous democracy without full indexation of wages and prices, inflation hurts the poor who have the most votes. Therefore, democratic accountability also acts to force the CB to keep inflation low, not high as in mature economies. It is the fiscal authority that is tempted into excess populist expenditures, forcing the $\mathrm{CB}$ to accommodate fiscal needs, while using distorting administrative measures, including credit controls, to keep inflation low.

A democratically accountable Central Banker in a developing democracy would anyway keep inflation low, so if stricter rules restrain fiscal populism the CB can focus less on inflation and more on growth. More autonomy to the CB can, without changes in the rules of the game through fiscal reform, lead to higher interest rates that increase the burden of public debt and have a high output cost. CBs are accountable if they are partially independent. Too much independence can reduce democratic accountability. One way to prevent this is to allow instrument but not goal independence. The government sets the social goal but the CB is free to implement it using its professional competence and knowledge (Goyal, 2002, 2007).

\section{IV.1 Precedents and path dependence}

Pre independence the discussion preceding the setting up of the RBI emphasized the importance of setting up an institution free of political influence ${ }^{12}$. There was a debate, but even those on opposite sides agreed on the importance of at least instrument independence. Under the pre-independence RBI Act it was obligated to carry out the responsibilities laid on it by Statute. It was nationalized at independence, but under the constitution and the division of responsibilities, if the RBI said no to the

\footnotetext{
${ }^{12}$ The cynics view was this was to ensure the country remained solvent and could continue to make payments to the British (see Anjaneyulu et. al. 2010).
} 
finance minister, the government would have to go to Parliament, which could assert some discipline.

But the early view of planning as a national goal established precedents and procedures that vitiated the autonomy of the RBI. The initial jockeying between the RBI and the Ministry of Finance ${ }^{13}$ made it clear the RBI was to be regarded as a department of the government. Monetary policy was another instrument to achieve national goals. The RBI lost even instrument independence.

"For the Reserve Bank of India therefore, short-term monetary policy meant not merely managing clearly identified variables such as the price level or the exchange rate, but doing so consistent with supporting a given Plan effort. ... The practical necessities of decision making under multiple constraints often led to the adoption, sometimes against the better judgment of its officers if not always of the Bank, of measures which created bigger problems in the longer-term than the more immediate ones they helped resolve. As the logic of decision-making became endogenized in the form of precedents and institutional evolution, the course was set for departures which however small or partial in the beginning, exercised over a period of time a tangible influence on the overall effectiveness of the Bank's monetary policy (Balachandran, 1998, pp. 10)"

An example of such a precedent was the RBI's agreement to the Government's January 1955 proposal to create ad hoc treasury bills to maintain the Government's cash balances at 50 crores or above, thus making soft credit available to the government in unlimited quantities. With the aid of this facility, the issue of ad hocs rose during the second plan. The Government also reduced safeguards restricting currency expansion.

The RBI's early conservative CB stance changed by the second Plan to one that supported the Government's financing requirements. By 1967 the heterodox 1951 Yojana Bhavan perspective on monetary policy had become the orthodox RBI view-

\footnotetext{
${ }^{13}$ In the mid-fifties Rama Rau, the then governor of the RBI resigned because of pressures from the Finance Minister TT Krishnamachari. The latter imposed a steep rise in the stamp duty of bills that effectively destroyed the bill market that Rama Rau was keen to develop.
} 
it had adopted and internalized the opposite government view. Where the Government pulled the RBI found itself following.

The government wanted lower interest rates given its large borrowings, and this made it difficult for the RBI to raise rates ${ }^{14}$. The RBI early showed itself to be susceptible to pressures to support government borrowing through the Gsecs. Even in 1951 banks were given an exemption from showing capital losses from their holdings of Gsecs on their balance sheets (Balachandran, 1998, pp. 55). As manager of the government debt the RBI generally sought to support the government borrowing program.

Independence depended also on personalities. Governor Bhattacharyya raised the Bank Rate over 1963-65, for the first time after 1957. In the early fifties, under Rama Rau, the Bank Rate was changed, and there were attempts to develop an active bill market for short-term financing. In the 1920s and 1930s an active bill market had provided seasonal finance.

In 1962 Iengar pointed out four areas of conflict between the Government and the RBI: interest rate policy, deficit financing, cooperative credit policies and management of sub standard banks. The RBI had worked towards larger sized financially viable rural cooperatives that would have eliminated the middleman. But the government destroyed these initiatives by insisting on village level cooperatives and on using rural credit as patronage. There were dissenting voices to the path the country and its institutions were taking (Chandavarkar, 2005). An article in the Hindu commenting on an early RBI committee pointed to the dangers of entrenching State control and distrust of the individual (Balachandran, 1998, pp. 241). It was feared the government's top down approach towards the cooperative movement would reduce self-reliance and increase dependence on the State.

In 1967 Governor Jha stated that given the plans, it was not possible to control aggregate credit. So the RBI should focus on controlling sectoral credit to achieve its twin goals of development and stability (Balachandran, 1998, pp. 730). Worried about

\footnotetext{
${ }^{14}$ In 1964-65 Finance Minister TT Krishnamachari even claimed for the Government the right to announce Bank rate changes when Parliament was in session. But Bhattacharyya was able to defend the Bank's right to announce the Bank Rate, and was also able to raise rates. Even such "symbolic" rights are important for autonomy (pp. 741 Balachandran, 1998).
} 
the effect of steady monetization of deficits on the money supply, the Bank fought for and got additional powers in 1956, by expanding section 42 of the RBI Act, to give it control over banks' cash reserves. A 1962 modification gave it the power to vary the CRR between 3 and 15 percent of scheduled bank's demand and time liabilities. The liquidity provisions of the Banking Companies Act were also changed and termed the Statutory Liquidity Ratio (SLR). It was now possible to use these to divert bank resources for government financing, while reducing money supply.

The economy had always been vulnerable to the monsoon. In the early seventies oil shocks were a new kind of supply shock. The Government and the RBI were afraid of high inflation. The new instruments enabled a squeeze on money and credit in response to supply shocks, which intensified the demand recession that followed. This discouraged growth and productivity increases that would have lowered inflation from the cost side.

The stagnation in the economy, rising government indebtedness, and scarcity of foreign exchange precipitated a balance of payment crisis in the early nineties. More openness was regarded as a solution. This was the way the rest of the world was going and was also in line with current dominant global ideas. But more openness required more credible institutions. Poor fiscal finances had precipitated many outflows and currency crises in emerging markets. Therefore liberalizing reforms in the nineties strengthened the autonomy of the RBI compared to the Government. Ad hoc treasury bills and automatic monetization of the deficits was stopped in the 90s. The Ways and Means Advance (WMA) system was started in 1997. Primary issues of government securities no longer devolved on the RBI. From April 1, 2006, the RBI no longer participated in the primary auction of government securities.

\section{IV.2 Strengthening institutions}

A Fiscal Responsibility and Budget Management (FRBM) Act was enacted by Parliament in 2003. The Rules accompanying the FRBM Act required the Centre to reduce the fiscal deficit to 3 per cent of GDP and, eliminate revenue deficit by March 31, 2008. The budget was to each year place before Parliament the Medium Term Fiscal Policy, Fiscal Policy Strategy and Macroeconomic Framework statements. Monetization of the deficit was banned, but there were no restrictions on OMOs. Any 
deviations from the FRBM Act require the permission of Parliament. If the targets were not met, a pro-rata cut on all expenditures was to be imposed without protecting capital expenditure. There is also a ceiling on guarantees. But the ceilings were allowed to be exceeded during "national security or national calamity or such other exceptional grounds as the Central Government may specify", so that the Government could legislate itself out of the commitments. As it did after the Lehman crisis when it deviated from the mandated consolidation path, requesting the $13^{\text {th }}$ Finance Commission to set out a new path.

The FRBM Act brought down only reported deficits. The global crisis exposed the inadequate attention paid to incentives and escape clauses in formulating the Act. Loopholes were found to maintain the letter of the law even while violating its spirit. Off budget liabilities such as oil bonds were used to subsidize some petroleum products. Targets were mechanically achieved, compressing essential expenditure on infrastructure, health and education, while maintaining populist subsidies. The Act requires to be reframed to improve incentives for compliance. Expenditure caps that bite especially on transfers, while protecting productive expenditure, will create automatic counter-cyclical stabilization as tax revenue falls and deficits rise in a slowdown. They will also moderate the temptation to raise expenditure when actual or potential revenues rise. These are an example of automatic non-discretionary stabilizers. With phased caps on spending rather than on the deficit, the latter could increase in case of economic slowdown when revenues fall, thus allowing automatic macro-stabilization, and increasing the political feasibility of the scheme. The deficit should be allowed to vary over the cycle, that is, it should be cyclically adjusted.

In the Indian context, especially urgent are detailed expenditure targets for individual ministries, and levels of government, as part of improved accounting, including shifts from cash to accrual based accounts. These should change the composition of government expenditure towards productive expenditure that improves human, social, and physical capital, and therefore the supply response. Essential transfers must be better targeted to reduce waste, and the effectiveness of government expenditure improved. Any permanent rise in expenditure must be linked to a specific tax source. The 13th Finance Commission brought in some cyclical adjustment but did not built in better incentives for compliance. 
A more credible FRBM will allow better fiscal-monetary coordination. To use Woodford's (2003) terminology, an active monetary policy can support growth if fiscal policy passively follows the path of consolidation. They can then switch positions during a crisis with monetary policy passively supporting active fiscal stimuli. The more usual combination in post-reform India, as the RBI gained greater independence, was for both to be active, which harmed growth, as overall monetary tightening sought to compensate for fiscal giveaways. Sharp rise in policy and other liberalized interest rates lowered growth after the reforms. When Indian interest rates did fall after 2000, despite high government deficits, and aggressive sterilization, because international interest rates fell, growth was stimulated.

If fiscal legislation successfully shifts the composition of public expenditure, then openness gives an opportunity for monetary authorities to lower Indian real interest rates closer to world levels. Since accountability, in a democratic policy, forces the $\mathrm{CB}$ to keep inflation low, a weak constraint on the $\mathrm{CB}$-- such as medium-term inflation zone targeting - would be credible. This stabilizes inflation expectations, so that the cost of dis-inflation is lower. Thus, measures to change aggregate demand would be required only if inflation forecasts are outside the zone; otherwise productivity improvements can be allowed to decrease inflation in their own time, under expanding potential output. This gives sufficient discretion to smooth nominal interest rates and achieve the desired real interest rates (Goyal 2002).

\section{IV.3 Openness, markets and CB autonomy}

Threats to the autonomy of CBs come not only from the Government, but also from free capital flows. The Mundell-Fleming model tells us that with perfect capital mobility, static expectations, and a fixed exchange rate monetary autonomy is lost. Monetary policymakers often refer to this impossible trinity, indicating their helplessness before waves of foreign inflows, and the increasing dominance of the market. But internationally, and in India, the potential impact of monetary policy has increased with the reforms. First, exchange rate regimes in most countries, and especially in EMs like India, are somewhere between a perfect fix and a perfect float. Even partial flexibility of exchange rates gives some monetary autonomy. Second, the absence of complete capital account convertibility (as in India) opens up more degrees 
of freedom. Consider a triangle where the bottom two corners represent a fixed and a floating exchange rate and the line between them depicts the whole range of intermediate regimes. The upper point is a closed capital account, so that in approaching the bottom line convertibility gradually increases until perfect capital mobility is reached on the line. Therefore the impossible trinity is only one point of the triangle. Everywhere else there is varying degrees of monetary autonomy. So, in the net, more openness increased degrees of freedom for policy. The loss in freedom from capital flows was not large enough to nullify the freedom from deficit financing.

Deeper markets with greater interest sensitivity make monetary policy more effective. To the extent behaviour is forward-looking, taking markets into confidence, or strategic revelation of information, can sometimes help achieve policy objectives. But markets factor in news and the expected policy stance making it difficult for policy to go against market expectations. So, in a sense, monetary policy also looses autonomy to free markets. The latter demand transparency, and like predictability. But after the Global Financial Crisis it is recognized that price discovery in markets can deviate from fundamentals. Market efficiency does not always hold and markets do not satisfy rational expectations.

Markets can get caught in a trap of self-fulfilling expectations around unsustainable overleveraged positions. So it is necessary at times to focus expectations around better outcomes. This may involve surprising markets - creating news. Blinder et. al (2008) show that the two ways in which communication makes monetary policy more effective is by creating news or reducing uncertainty. Surprise can be compatible with more transparency if it is linked to random shocks to which the system is subjectthen communication enhances news (Goyal et. al 2009). Thus free markets also reduce $\mathrm{CB}$ autonomy but the global crisis has resulted in giving institutions and regulators some degrees of freedom. It has also led to a re-assessment of the CB's objective beyond a narrow focus on inflation targeting. Financial stability has been recognized as a major objective. As the regulator of banks, the RBI has always given priority to financial stability, and has effectively used macro-prudential instruments. These are now being recognized worldwide as necessary complements to the interest rate instrument. 


\section{IV.4 Bank Governors and Delegation in India}

One of the measures suggested in the literature to increase independence is to delegate authority to a conservative central banker, who will then impose own preferences on the growth inflation trade-off (Vasudevan, 2007).

\begin{tabular}{|c|c|c|c|c|c|c|c|}
\hline \multirow{3}{*}{ Governor } & \multirow{3}{*}{ From } & \multirow{3}{*}{ To } & \multirow{3}{*}{ Tenure Period } & \multicolumn{3}{|c|}{ Monetary Policy } & \multirow{3}{*}{$\begin{array}{l}\text { Real } \\
\text { GDP } \\
\text { Growth }\end{array}$} \\
\hline & & & & \multicolumn{3}{|c|}{ Growth Rates } & \\
\hline & & & & $\mathbf{R M}$ & M3 & WPI & \\
\hline Shri H.V.R. Iengar & Mar-57 & Feb-62 & $1957-58$ to $1961-62$ & 6.11 & 8.21 & 3.52 & 3.76 \\
\hline Shri P.C.Bhattacharya & Mar-62 & Jun67 & $1962-63$ to $1966-67$ & 8.16 & 9.93 & 7.28 & 2.42 \\
\hline Shri L.K. Jha & Jul-67 & May-70 & $1967-68$ to $1969-70$ & 7.97 & 12.23 & 8.58 & 5.73 \\
\hline Shri Jagannathan & Jun-70 & May-75 & $1970-71$ to $1974-75$ & 12.93 & 15.44 & 12.67 & 2.3 \\
\hline Shri I.G. Patel & Dec-77 & Sep-82 & $1977-78$ to $1982-83$ & 15.57 & 17.55 & 9.13 & 4.03 \\
\hline Shri Manmohan Singh & Sep-82 & Jan-85 & $1983-84$ to $1984-85$ & 23.46 & 18.60 & $7^{@}$ & 6 \\
\hline Shri R.N. Malhotra & Feb-85 & Dec-90 & $1985-86$ to $1990-91$ & 16.54 & 17.14 & 7.26 & 5.93 \\
\hline Shri S. Venkatiramanan & Dec-90 & Dec-92 & $1991-92$ to $1992-93$ & 12.35 & 17.05 & 11.9 & 3.2 \\
\hline Dr. C. Rangarajan & Dec-92 & Nov-97 & $1993-94$ to $1997-98$ & 15.64 & 17.72 & 7.6 & $6.62 *$ \\
\hline Dr. Bimal Jalan & Nov-97 & Sept-03 & $1998-99$ to $2002-03$ & 10.28 & 15.42 & 4.66 & 5.38 \\
\hline Dr. Y.V. Reddy & Sept-03 & Sept-08 & 2003-04 to 2007-08 & 20.43 & 18.58 & 5.29 & 9.01 \\
\hline Dr. D. Subbarao & Sept-08 & Current & $2008-09$ to $2009-10$ & 11.70 & 18.06 & 6.04 & 6.38 \\
\hline \multicolumn{8}{|c|}{$\begin{array}{l}\text { Source: For the period after 1970-71, Reserve Bank, before that reserve money (RM) is from IMF, Financial Statistics, and inflation } \\
\text { and output from NAS, CSO. Updated from Goyal (2007). }\end{array}$} \\
\hline \multicolumn{8}{|c|}{$\begin{array}{l}\text { Note: The last four columns give growth rates. The output figures from * refer to the New Series of the CSO, with base } 1993-94 \text {, prior } \\
\text { to that the base was } 1980-81 \text {. The inflation series are derived from the Wholesale Price Index, before }{ }^{\circledR} \text { the base is } 70-71 \text {, and } \\
\text { after it is } 81-82 \text {, and for the last three rows it is } 1993-94 \text {. }\end{array}$} \\
\hline
\end{tabular}

Table 7 shows growth, inflation and monetary policy have differed in the tenures of various Reserve Bank governors. The overall direction may have been dictated by the preferences of the elected government, given lack of constitutional autonomy. But the delegated agent, or the Governor, has been able to make a difference. The divergence in performance in the regimes of different governors suggests that their preferences affected growth rates. Second, governors in whose regime growth was higher have delivered lower inflation, since cost shocks normally sparked higher inflation, but the monetary response affected growth and future inflation. Short-run sharp inflation caused by supply shocks was controlled through a fall in demand, but it harmed longer-term growth. The clear differences in regimes suggest that governors whose policies discouraged recovery in growth ended up with higher inflation also (Goyal, 2007). The two governors with the highest rates of growth of reserve money, Dr. Manmohan Singh and Dr. Reddy, also had local maxima in rates of growth and minima in rates of inflation. 


\section{Outcomes}

Early monetary policy was geared to support planned expenditures and government deficits $^{15}$. During an agricultural shock monetary policy would initially support increased drought relief then tighten just as the lagged demand effects of an agricultural slowdown were hitting industry. Administered oil and food prices were normally raised with a lag after monetary lightening brought inflation rates down. Macro policy was thus pro-cyclical, but pervasive controls limited volatility.

\section{V.1 The historical trajectory}

Severe drought and terms of trade shocks over 1965-67, led to a fiscal tightening, with a cut in deficits and in public investment. Monetary policy following a credit targeting approach was non-accommodating but not severe. Fiscal-monetary policies were closely linked, as the budget deficit was automatically financed. Severe monetary and fiscal measures followed the oil price plus agricultural supply shock over 1973-75. In both cases there was an unnecessary loss of output. A focus on expanding supply would have been more effective. After the 1979-80 oil shock, a cut in public investment and sharp monetary tightening was avoided. Recovery was rapid, but deficits and supply side inadequacies continued.

The relatively closed, import substitution and public investment driven model of development followed, allowed macro-policy to be geared towards domestic requirements. As growth slowed, successful lobbying for subsidies could have led to increasing reliance on seignorage, since inflation is an easy-to-collect tax. But where more than half the population were below the poverty line and an even larger percentage had no social security or other protection against inflation, governments concerned with re-election could not afford high inflation. Thus, even though there was some positive seignorage revenue and automatic monetisation of the deficit, commercial banks' ability to multiply the reserve base and create broad money was partially countered through draconian compulsory reserve and statutory liquidity requirements. This, together with administered prices, restrained inflation to politically- acceptable levels. Thus, political business cycles in India largely took the

\footnotetext{
${ }^{15}$ The analysis in this section draws on RBI publications including monetary policy statements, speeches by RBI governors and data available on the RBI's website www.rbi.org.in and my earlier publications.
} 
form of a cut in long-term development expenditures and interventions that distorted allocative efficiency, not of increased money creation. The future was sacrificed to satisfy populism in the present (Goyal 1999).

Since the seventies, dominant development ideas changed to favour openness. In India also the ill effects of controls were becoming obvious. Some liberalization started in the mid-eighties, but a major thrust for external openness came from the mid 1991 balance of payment crisis when foreign exchange reserves were down to 11 days of imports. The crisis helped bring home the lesson that excessive interest controls and credit rationing were deleterious to growth and stability (Thorat, 2010). It made possible the implementation of the series of pending committee reports.

Current account and partial capital account liberalization, and a gradual move to more flexible exchange rates followed. Sequencing was well thought out. While controls continued on domestic portfolios and debt inflows, equity inflows were liberalized. Equity shares risks, while short-term debt flows create a heavy repayment burden in adverse times. On foreign debt, the sequence of relaxation favoured commercial credit and longer term debt (Rangarajan 2002, 2004). Major reforms were undertaken towards development of equity, forex money and government securities markets. Although low by developing country standards, Indian inflation was higher than world rates. Accumulation of large public debt made the fiscal-monetary combination followed in the past unsustainable. The automatic monetisation of the government deficit was stopped and auction based market borrowing adopted for meeting the fiscal deficits. The repressed financial regime was dismantled, interest rates became more market determined and the government began to borrow at market rates.

Bank liquidity funded speculative buying through repurchase transactions in government securities and bonds. These stock market scams led to further action to remove weaknesses such as lack of transparency in the market infrastructure for government securities, excess liquidity with public sector undertakings, inadequate internal controls due to low levels of computerization and reliance on manual processing, which made the nexus between banks and brokers feasible. All administered interest rates were deregulated except the savings bank deposit rate. RBI initiated a delivery versus payment mechanism for settlement of trades in government 
securities was, leading to establishment of the CCIL (Clearing Corporation of India), a central counterparty to undertake guaranteed settlement for government securities, repos in Gsecs and forex market trades.

As the bank regulator, RBI was an early pioneer in countercyclical prudential regulations that are being adopted worldwide after the global financial crisis. Provisioning for bank housing and commercial real estate loans was raised as a countercyclical measure when Indian real estate prices rose after 2005. Accounting standards did not permit recognition of unrealized gains in equity or the profit and loss account, but unrealized losses had to be accounted. The relative conservativeness, without full marking-to-market requirements, reduced pro-cyclical incentives. Banks were required to mark-to-market only investments held in trading categories. Exposures had conservative capital adequacy requirements under 2006 guidelines on securitization. Any profits on sale of assets to a special purpose vehicle were to be recognized only over the life of the pass through certificates issued, not immediately on sale (Goyal 2009). These types of prudential regulations affect behaviour while minimizing high transaction costs imposed by discretionary credit controls. They give a powerful additional weapon to prevent asset price bubbles, allowing the policy rate to focus on the real sector. In a more complex economy, credit controls become difficult for the regulator to operate, apart from the distortions they cause. By 1994 selective credit control operations had been largely phased out.

The basic objectives of monetary policy remained price stability and development, but in line with the recommendations of the Chakravarty Committee (RBI, 1985), the operating procedures had shifted from credit controls towards flexible monetary targeting with 'feedback' from the mid 1980s till 1997-98. But deregulation and liberalization of the financial markets combined with the increasing openness of the economy in 1990s made money demand more unstable, and money supply more endogenous. The RBI itself noted monetary policy based on demand function of money, in these circumstances, was expected to lack precision (Reddy 2002).

The informal nominal money supply targeting proved inadequate under these changes; interest rates were volatile in the 1990s. After the adverse impact of the nineties peak in interest rates, the Reserve Bank moved towards using the interest rate 
as an instrument, basing its actions on a number of indicators of monetary conditions (Jalan 2001). It formally adopted a 'multiple indicator approach' in April 1998, following informal changes in practice from the mid nineties ${ }^{16}$. There was no formal inflation targeting, but policy statements gave both inflation control and facilitating growth as key objectives. A specific value of 5 percent was given as the desirable rate of inflation, with the aim to bring it even lower in the long-term. The aim was to reduce reliance on reserve requirements, particularly the Cash Reserve Ratio (CRR), shifting liquidity management towards OMOs in the form of outright purchases/sales of Gsecs and repo and reverse repo operations. Table 8 summarizes these changes.

\begin{tabular}{llll}
\hline \multicolumn{3}{c}{ Table 8: Monetary Policy Procedures } \\
$\begin{array}{l}\text { Monetary } \\
\text { Policy }\end{array}$ & 1950s to End 1980s & Early 1990s to 1998-99 & 1998-99 to Present \\
\hline Objectives & $\begin{array}{l}\text { 1) Stability } \\
\text { 2) Development }\end{array}$ & $\begin{array}{l}\text { 1) Inflation } \\
\text { 2) Credit supply for growth }\end{array}$ & $\begin{array}{l}\text { 1) Inflation } \\
\text { 2) Growth }\end{array}$ \\
$\begin{array}{l}\text { Intermediate } \\
\text { target }\end{array}$ & $\begin{array}{l}\text { Priority sector credit } \\
\text { targeting }\end{array}$ & $\begin{array}{l}\text { Monetary targeting with } \\
\text { annual growth in broad } \\
\text { money }\left(\mathrm{M}_{3}\right) \text { as intermediate } \\
\text { target }\end{array}$ & $\begin{array}{l}\text { Multiple indicator approach } \\
\text { (namely money, capital, } \\
\text { currency, external etc.) as } \\
\text { intermediate target }\end{array}$ \\
$\begin{array}{l}\text { Operating } \\
\text { procedure } \\
\text { (Instruments) }\end{array}$ & $\begin{array}{l}\text { Direct instruments } \\
\text { (interest rate } \\
\text { regulations, selective } \\
\text { credit control, SLR },\end{array}$ & $\begin{array}{l}\text { Gradual interest rate } \\
\text { deregulation CMR; Direct } \\
\text { instruments (selective } \\
\text { credit control, SLR, CRR) }\end{array}$ & $\begin{array}{l}\text { Direct (CRR, SLR) and } \\
\text { indirect instruments (repo } \\
\text { operations under LAF and } \\
\text { OMOs) }\end{array}$ \\
\hline
\end{tabular}

\section{V.2 Excess demand or cost shocks?}

The official understanding of monetary policy in India is that huge monetary overhang built up due to financing of large fiscal deficits created excess demand that had to be sharply reduced during periods of high inflation. But Mohanty (2010) in his Table 2 shows that every period of double-digit inflation in India was associated with a supply shock.

\footnotetext{
${ }^{16}$ A vector autoregression model following Christiano et. al (1999) showed the growth of reserve money better indicates the stance of monetary policy for 1985 M1 to 1995 M12 and call money rate for 1996M1 to 2005M3. This supports the changing operating procedure of monetary policy in India from quantity to rate variables. The results of forecast error variance decomposition for the later sub period show shocks to exchange rate to be important in explaining unexplained variance of inflation, movements of credit and money supply growth. These findings highlighted the growing importance of the exchange rate channel. While agricultural shocks were the main driving factor of domestic inflation from mid 80 s to mid 90 s, their explanatory power went down substantially post-reform. International factors became the main drivers of Indian inflation (Agrawal, 2008).
} 
Chart 4 shows growth of reserve money (RM), broad money (M), and real GDP since the fifties. Chart 5 shows WPI inflation. RM shows large fluctuations from the seventies, demonstrating the limited control left with the RBI. The fluctuations reduce in the 90 s after the removal of automatic monetization. But large inflows push it up again in the 2000s. The fluctuations in broad money are much lower, however, demonstrating the greater control the RBI exerted through use of the CRR and SLR. The early large fluctuations in output growth and inflation both occur during period of supply shocks, and both are moderated from the mid-nineties.

\begin{tabular}{lllllll}
\hline \multicolumn{6}{c}{ Table 9: Policy and Outcomes in High Inflation and other Years } \\
\hline Years & Demand Shock & $\begin{array}{l}\text { Demand Shock } \\
\text { without CAD }\end{array}$ & Policy Shock & Credit Shock & $\begin{array}{l}\text { Real GDP } \\
\text { Growth }\end{array}$ & WPI Inflation \\
\hline \multicolumn{5}{c}{ Average Annual Growth Rate } \\
\hline $1953-56$ & 0.5 & 0.6 & 1.4 & 4.2 & 4.7 & -3.3 \\
$\mathbf{1 9 5 6 - 5 7}$ & $\mathbf{- 1 . 8}$ & $\mathbf{0 . 6}$ & $\mathbf{- 2 . 2}$ & $\mathbf{- 7 . 5}$ & $\mathbf{5 . 6}$ & $\mathbf{1 4 . 0}$ \\
$1957-64$ & -0.8 & -0.9 & 0.6 & 0.4 & 4.0 & 3.9 \\
$\mathbf{1 9 6 4 - 6 5}$ & $\mathbf{1 . 0}$ & $\mathbf{1 . 3}$ & $\mathbf{- 0 . 3}$ & $\mathbf{- 3 . 4}$ & $\mathbf{7 . 5}$ & $\mathbf{1 1 . 0}$ \\
$1965-66$ & 2.2 & 2.2 & 1.4 & 3.3 & -2.7 & 7.6 \\
$\mathbf{1 9 6 6 - 6 7}$ & $\mathbf{2 . 1}$ & $\mathbf{3 . 0}$ & $\mathbf{- 1 . 5}$ & $\mathbf{- 0 . 5}$ & $\mathbf{0 . 0}$ & $\mathbf{1 3 . 9}$ \\
$1967-72$ & -0.4 & -0.8 & 0.2 & 3.0 & 4.9 & 5.0 \\
$\mathbf{1 9 7 2 - 7 5}$ & $\mathbf{0 . 4}$ & $\mathbf{0 . 5}$ & $\mathbf{- 0 . 8}$ & $\mathbf{0 . 5}$ & $\mathbf{1 . 3}$ & $\mathbf{1 8 . 5}$ \\
$1975-79$ & 0.8 & 0.5 & 1.8 & 6.5 & 6.0 & 1.6 \\
$\mathbf{1 9 7 9 - 8 1}$ & $\mathbf{- 0 . 9}$ & $\mathbf{- 0 . 3}$ & $\mathbf{- 0 . 2}$ & $\mathbf{4 . 8}$ & $\mathbf{0 . 8}$ & $\mathbf{1 7 . 7}$ \\
$1981-90$ & -0.3 & -0.2 & 0.7 & 3.0 & 5.6 & 6.8 \\
$\mathbf{1 9 9 0 - 9 2}$ & $\mathbf{- 0 . 9}$ & $\mathbf{- 1 . 9}$ & $\mathbf{- 1 . 4}$ & $\mathbf{- 1 . 8}$ & $\mathbf{3 . 3}$ & $\mathbf{1 2 . 0}$ \\
$1992-94$ & -0.7 & -0.6 & 0.1 & -0.9 & 5.1 & 9.2 \\
$\mathbf{1 9 9 4 - 9 5}$ & $\mathbf{1 . 1}$ & $\mathbf{1 . 7}$ & $\mathbf{0 . 1}$ & $\mathbf{3 . 2}$ & $\mathbf{6 . 7}$ & $\mathbf{1 2 . 6}$ \\
$1995-08$ & 0.4 & 0.4 & 0.1 & 5.6 & 7.0 & 5.1 \\
$\mathbf{2 0 0 8 - 0 9}(\mathbf{Q E E})$ & $\mathbf{- 0 . 9}$ & $\mathbf{0 . 2}$ & $\mathbf{0 . 4}$ & $\mathbf{1 3 . 5}$ & $\mathbf{6 . 8}$ & $\mathbf{8 . 3}$ \\
\hline
\end{tabular}

Note: Figure in bold indicate the years in which inflation was in double digits.

CAD- Current Account Deficit; WPI- Wholesale Price Index; GDP- Gross Domestic Price

Table 9 helps to further understand these charts. It captures the monetary and fiscal response to supply shocks in the "Policy" variable. Measuring the policy response to an exogenous shock helps to cut through the endogeneity plaguing macroeconomic systems. The policy reaction responds to the shocks and affects the outcomes in such episodes. The policy shock is calculated as the rate of change of reserve money, Central Government revenue, and capital expenditure each as a percentage of GDP. That is, period $t$ gives the total of the three variables each minus their respective 
values in period $\mathrm{t}-1$. This is then averaged to get per annum rates for periods of double digit inflation (each associated with a supply shock) and others. A negative value implies policy contraction exceeding that in GDP. The table shows this to be negative in years when the GDP growth rate fell due to an external shock. Thus policy amplified shocks.
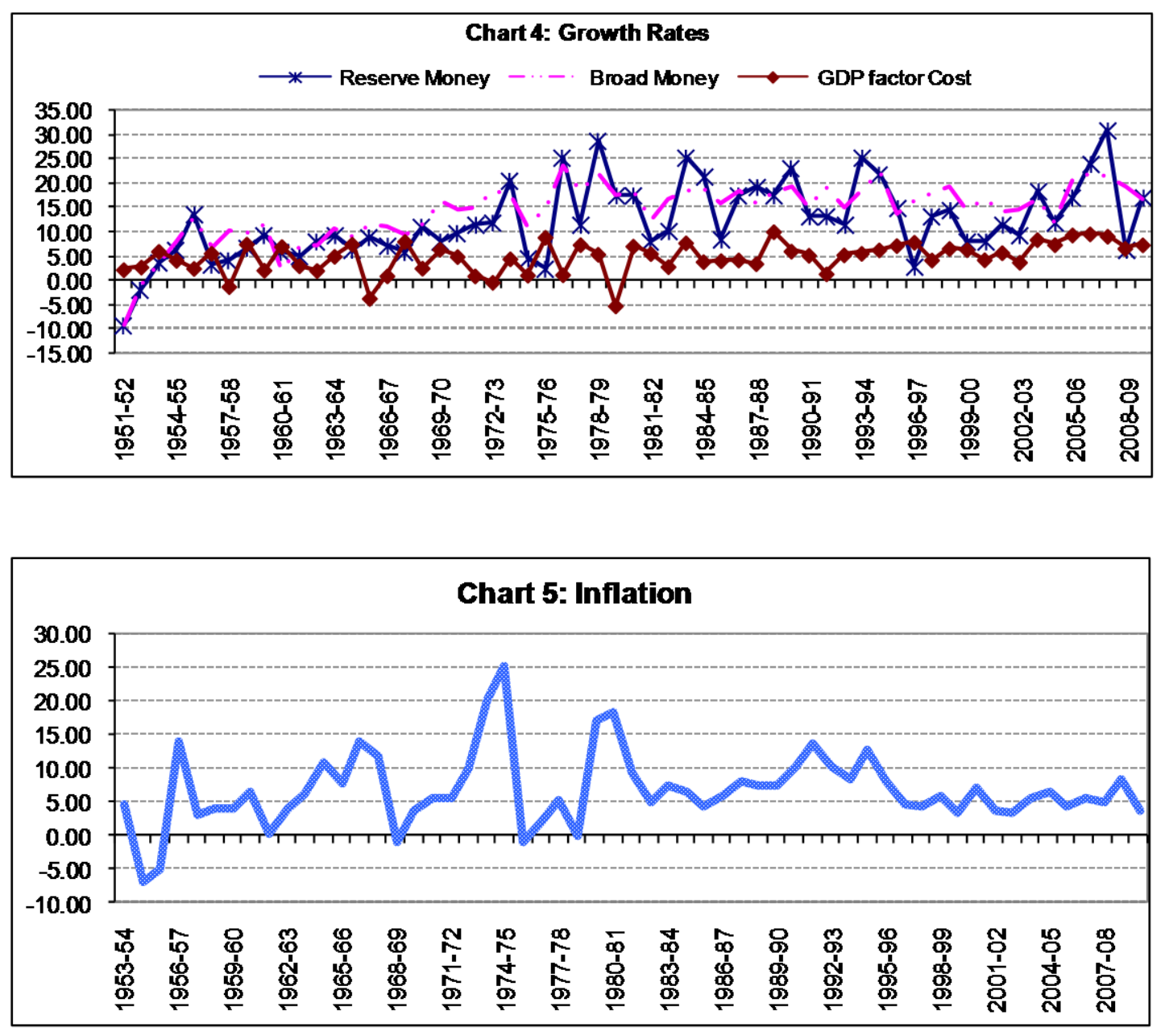

The "credit" variable does a similar calculation for broad money M3, bank credit to the commercial sector and total bank credit, capturing outcomes of policy tightening. This was more severe in the earlier shocks. The availability of more financial substitutes and of external finance reduced the impact of policy tightening on credit variables. In the later years policy was acting more through prices (interest rate changes) than quantities. 
Finally the "demand" variable is the sum of changes in private final consumption expenditure (PFCE), government expenditure (G), Gross Domestic Capital Formation (GDCF), and current account deficit (CAD) as a percentage of GDP. It is also given without $\mathrm{CAD}^{17}$. Thus each shock plus the policy response imparted a considerable negative impulse to aggregate demand. While the supply shock pushed up the AS of section III, the policy response shifted the AD leftwards. Demand remained positive through the first oil shock years but fell steeply in 1975-76. It was consistently negative through the eighties, the years of largest fiscal deficits and RBI accommodation when the so-called "monetary overhang" was developed. But there was no excess demand! Since the table measures final demand categories, this suggests the large government transfers made for the poor were being siphoned away, perhaps abroad, without reaching beneficiaries ${ }^{18}$. Policy shocks were no longer negative after the mid-nineties, helping explain the better performance. They were actually countercyclical ${ }^{19}$ and positive during the global financial crisis.

Thus for much of the period, policy contraction exceeded that in GDP in years when the GDP growth rate fell due to an external shock, imparting a considerable negative impulse to aggregate demand.

\section{V.3 Openness, inflows and policy}

The other major change with greater openness was the higher level of foreign inflows. Even gradual and sequenced capital account convertibility led to large inflows of foreign portfolio investment (FPI). The RBI's acquisition of foreign assets was now driving reserve money growth as RBI credit to the Government contracted. Reserves of foreign currency accumulated, and were sterilized by a contraction of RBI credit to

\footnotetext{
${ }^{17}$ A large CAD implies domestic resources are less than domestic requirements, but it is a consequence of domestic demand, rather than an additional demand component. A CAD implies domestic demand is leaking abroad. Including it reduces demand even more as it widens during downswings in India. Goyal (2011b) does a similar analysis for the individual years of external shocks.

${ }^{18}$ GFI (Global Financial Integrity) (2010) estimates that tax evasion, crime, and corruption have removed gross illicit assets from India worth US \$462 billion since independence.

${ }^{19}$ Dash and Goyal (2000) found monetary policy broadly succeeded in preventing an explosive growth in money supply and reined in inflationary expectations. But by targeting manufacturing prices it harmed real output. Their estimations implied it would be more efficient to target agricultural prices for inflation control. A monetary contraction should be completed earlier than in the past, and should coincide with a rise in food prices. Information available in the systematic structural features was not exploited in designing monetary policy. Reserve Bank monetary control had intensified shocks to real output, while being unable to prevent the expansion of credit in response to a speculative profit motive.
} 
the government, and through OMOs. The latter became possible by the mid-1990s because of the financial liberalization of the previous decade; the debt market was deepening and government debt could be traded at market-determined rates. But OMOs remained minor for fear of their impact on the cost of government borrowing. The market was expected to discipline government borrowing but as real interest rates rose and growth rates fluctuated, government debt burden increased.

The CRR ratios that were being brought down in line with the committee recommendations had to be raised again in a burden sharing arrangement whereby the costs of sterilization were to be shared by the government, RBI and banks. Table 10, 11 show the changes in India's openness across the decades. Reserves ${ }^{20}$ as a ratio of GDP went from a low of 1.35 in the early years to a high of 14.84. Exports plus imports jumped from a stagnant 8-11 percent of GDP in the first 40 years after independence to 25 percent. The dependence on oil imports increased. While the current account of the balance of payments remained negative, the capital account jumped to about 3 percent of GDP. Exchange rate depreciation was particularly large in the first reform decade.

\begin{tabular}{lllllll}
\hline \multicolumn{7}{c}{ Table 10. Average Annual Growth Rates } \\
\hline & Reserves & $\begin{array}{l}\text { Exports } \\
\text { (f.o.b) }\end{array}$ & $\begin{array}{l}\text { Import } \\
\text { (c.i.f) }\end{array}$ & $\begin{array}{l}\text { Growth of } \\
\text { Oil } \\
\text { Imports }\end{array}$ & $\begin{array}{l}\text { Growth of } \\
\text { Non Oil } \\
\text { Imports }\end{array}$ & $\begin{array}{l}\text { Exchange } \\
\text { Rate } \\
\text { Depreciation/ } \\
\text { Appreciation }\end{array}$ \\
\hline $1951-52$ to 1959-60 & -9.13 & 0.36 & 7.17 & - & - & 0 \\
$1960-61$ to 1969-70 & 10.79 & 8.87 & 6.63 & - & - & 5.15 \\
$1970-71$ to 1979-80 & 25.26 & 16.76 & 20.88 & 53.47 & 19.17 & 0.898 \\
$1980-81$ to 1989-90 & 1.79 & 16.62 & 15.67 & 12.14 & 16.45 & 7.26 \\
$1990-91$ to 1999-00 & 43.12 & 19.46 & 20.01 & 24.48 & 17.91 & 10.59 \\
$2000-01$ to 2009-10 & 23.35 & 18.53 & 20.17 & 23.56 & 22.44 & 1.32 \\
\hline
\end{tabular}

Post reform macro-stabilization included a cut in public investment, monetary tightening partly to sterilize capital inflows and an artificial agricultural supply shock as procurement prices for food grains were raised. A benchmark real effective

\footnotetext{
${ }^{20} \mathrm{FX}$ reserves rose to over 300 billion US dollars in 2011, compared to a paltry 5 billion in 1990-91. 30 billion dollars were accumulated in just 18 months over January 2002 to August 2003. Other years of large inflows were 2007 and 2010. Outflows occurred after the global crisis in 2008, but were soon reversed. Arbitrage occurred at the short end since Indian short real rates were kept higher than US rates.
} 
exchange rate was set after two-stage devaluation in the early nineties, in order to maintain a competitive real exchange rate and encourage exports to aid absorption of excess labour. It was largely maintained. The nominal rate was kept stable for long periods of time, and reserves accumulated under inflows. Growth revived in 1993-94, and monetary policy was accommodating, but exchange rate volatility in 1995 led to a monetary squeeze that precipitated a slowdown. The monetary stance was relaxed, but reversed again at the first sign of exchange rate volatility. Periodic bursts of volatility, sometimes induced by fluctuations in foreign capital inflows, for example from midMay to early August 2000, were suppressed. But the sharp jump in interest rates triggered an industrial recession and sustained it over 1997-2001. Goyal (2005) shows in this slowdown period, foreign financial inflows measured as the surplus on the capital account rose, but their volatility fell. The volatility of the CAD, however, rose, suggesting it was policy that was creating volatility in the absorption of inflows. The CAD, which is the difference between investment and domestic savings, is affected by general macroeconomic policy.

\begin{tabular}{llllllll}
\hline \multicolumn{7}{c}{ Table 11: Ratio to GDP Market Price (percentage) } \\
\hline & Reserves & $\begin{array}{l}\text { Exports } \\
\text { (f.o.b) }\end{array}$ & $\begin{array}{l}\text { Import } \\
\text { (c.i.f) }\end{array}$ & $\begin{array}{l}\text { Current } \\
\text { Account }\end{array}$ & $\begin{array}{l}\text { Capital } \\
\text { Account }\end{array}$ & $\begin{array}{l}\text { Oil } \\
\text { Imports }\end{array}$ & $\begin{array}{l}\text { Non Oil } \\
\text { Imports }\end{array}$ \\
\hline 1951-52 to 1959-60 & 6.56 & 5.13 & 6.79 & -0.81 & 0.27 & - & - \\
$1960-61$ to 1969-70 & 1.35 & 3.11 & 5 & -1.61 & 1.57 & - & - \\
$1970-71$ to 1979-80 & 2.3 & 3.76 & 4.61 & -0.1 & 0.59 & 1.31 & 4.09 \\
$1980-81$ to 1989-90 & 2.45 & 4.02 & 6.84 & -1.43 & 1.23 & 2.01 & 5.14 \\
$1990-91$ to 1999-00 & 4.75 & 6.72 & 9.07 & -1.22 & 1.98 & 2.11 & 7.11 \\
$2000-01$ to 2009-10 & 14.84 & 10.3 & 14.57 & -0.32 & 2.85 & 4.92 & 1.73 \\
\hline
\end{tabular}

Although the exchange rate was said to be market determined, massive RBI intervention continued in order to absorb foreign portfolio inflows. Trend depreciation was facilitated through the nineties to cover the inflation differential. There was some appreciation due to the weakening of the dollar from 2002 and from 2004 there was mild two-way movement of the nominal exchange rate (Chart 6). Foreign exchange reserves accelerated in this period. The nominal exchange rate was now a managed float. There was occasional excess volatility, but a crisis was avoided. Even contagion from the East Asian crisis was averted. Some agricultural liberalization and falling world food prices did reduce the political pressures that had raised food support prices 
and inflation, but exchange rate policy was not systematically used to moderate the effect of the typical EM supply shocks: oil price shocks and failure of rains.

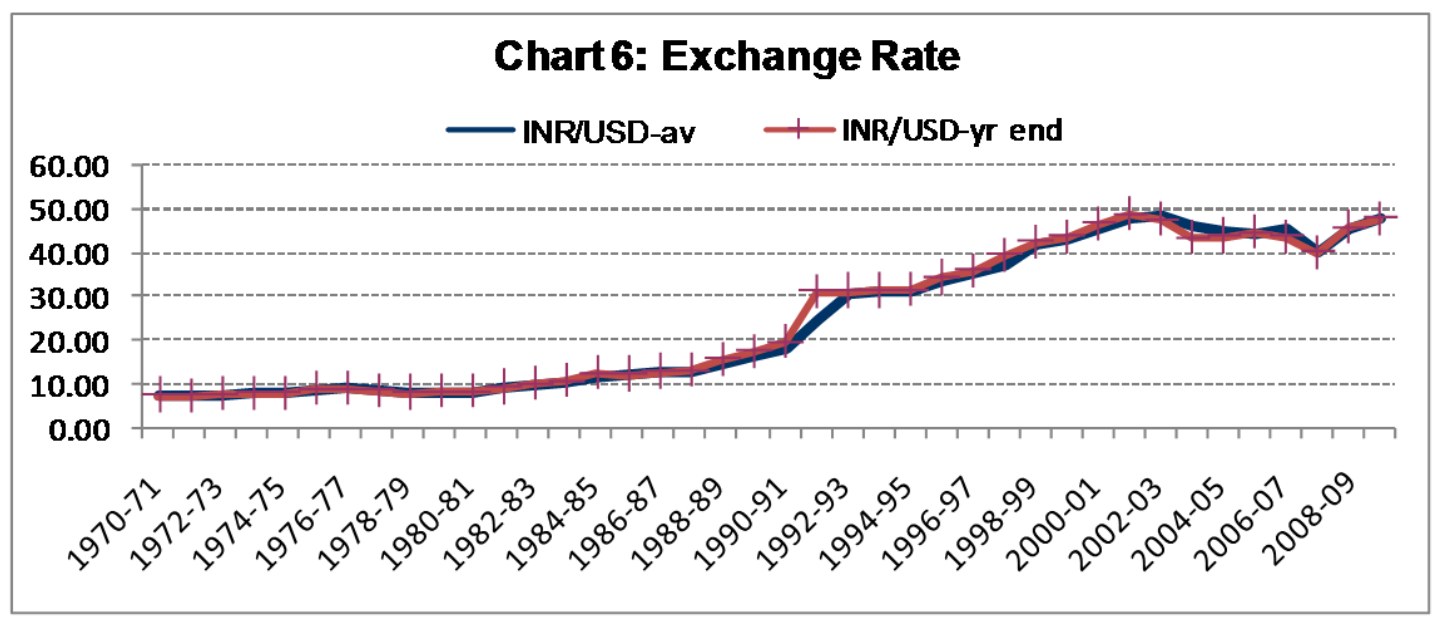

Growth rates, moreover, were lower than potential. Monetary tightening in the presence of supply shocks sustained the slowdown. Steady softening of nominal interest rates occurred only after February 2001, as world interest rates fell. A new RBI Governor, Bimal Jalan, demonstrated, through staggered placement of government debt, that it was possible for interest rates to come down despite high fiscal deficits and committed to a soft interest rate regime even while preventing excess volatility of the rupee. So there were reversals during periods of exchange rate volatility. In 199899 the decision not to tighten monetary policy when inflation peaked with certain food prices turned out to be correct as inflation fell. Similarly inflation fell again as the oil shock wore out, without a sharp tightening in monetary policy, both in 200001 , and in early 2003-04.

Sharp defensive rise in interest rates after shocks were, however, implemented given policy makers' perception that interest elasticities were $\operatorname{low}^{21}$. Interest rates had been

\footnotetext{
${ }^{21}$ Monetary policy shocks were identified using a short-run vector autoregression model. The identification assumption on contemporaneous causality used to isolate the policy shocks was exogenous shocks (foreign oil price inflation and interest rates), and domestic variables (inflation, IIP growth and exchange rate changes) affect the policy instrument variable (call money rates, or treasury bill rates) contemporaneously, but the policy variables affect them only with a lag. All these variables go on to affect gross bank credit and the broad monetary aggregate (M). Domestic variables do not enter the lag structure of the foreign variables since the Indian economy is too small to affect international prices. The RBI's reaction function or feedback rule to changes in the foreign shocks and non-policy variables determines the setting of the policy instrument variable. The policy shock is the residual from this estimated "reaction" of the RBI. It is orthogonal to the variables in the RBI's feedback rule. The residuals of the 'monetary policy instrument' equation give an estimate of the large monetary policy shocks in this period (Goyal 2008b).
} 
only recently freed; the impact of reforms on elasticities, in particular the impact of the interest rate on consumer spending, was not yet fully understood. In addition, political pressures made the weight given to inflation in the loss function high. The RBI had greater autonomy after the reforms, but was not fully independent. The fiscal deficit was thought to be large. There were doubts about the durability of capital inflows and fears of a possible reversal, which would have implied a shock to the risk premium. There was a perception that markets create excess volatility. Finally, risk aversion explained the use of the interest rate defense.

Inflation fell in the late nineties, with the improvements in productivity, and the influence of low global inflation in a more open economy, but industrial growth did not revive until 2003, when Indian interest rates followed falling global rates and public expenditure on infrastructure rose. The lowering occurred not from a conscious policy decision but because international interest rates were falling. Even with higher growth and an extended period of high global oil prices, inflation remained low.

\section{V.4 Money markets and interest rates}

Throughout this period, gradual financial reforms deepened markets. As most interest rates stopped being administered, it became a more effective policy instrument. The liquidity adjustment facility (LAF) implemented around that time helped fine-tune domestic liquidity and short-term interest rates drifted downwards. The absence of a reversal since 2000, contributed to an upswing in activity, as benign markets expectations strengthened. Bursts of high volatility in exchange rates were absent during this period. FX markets had the highest growth rates in the world. The fiscal deficit fell after a long time, with higher growth and lower interest rates, when the opposite policy of periodic rise in interest rates had not succeeded over 1997-02.

The repo and reverse repo rates began to be changed frequently and smoothly, and the call money rate largely stayed within the band determined by them. Charts 7 to 11 show the changes in the interest rate regime, the increasing sophistication of markets, and market determination of rates. The RBI's general refinance rate, the Bank Rate, peaked in the early nineties and fell after that, but was not changed very frequently (Chart 7). Volatility in the call money rate (CMR) was much lower after the mid- 
nineties. Although liberalization initially increased the volatility of rates in a thin market, it eventually brought down the volatility to levels prevailing when rates were tightly administered, as markets deepened. But now rates came through a complex market process (Chart 8).
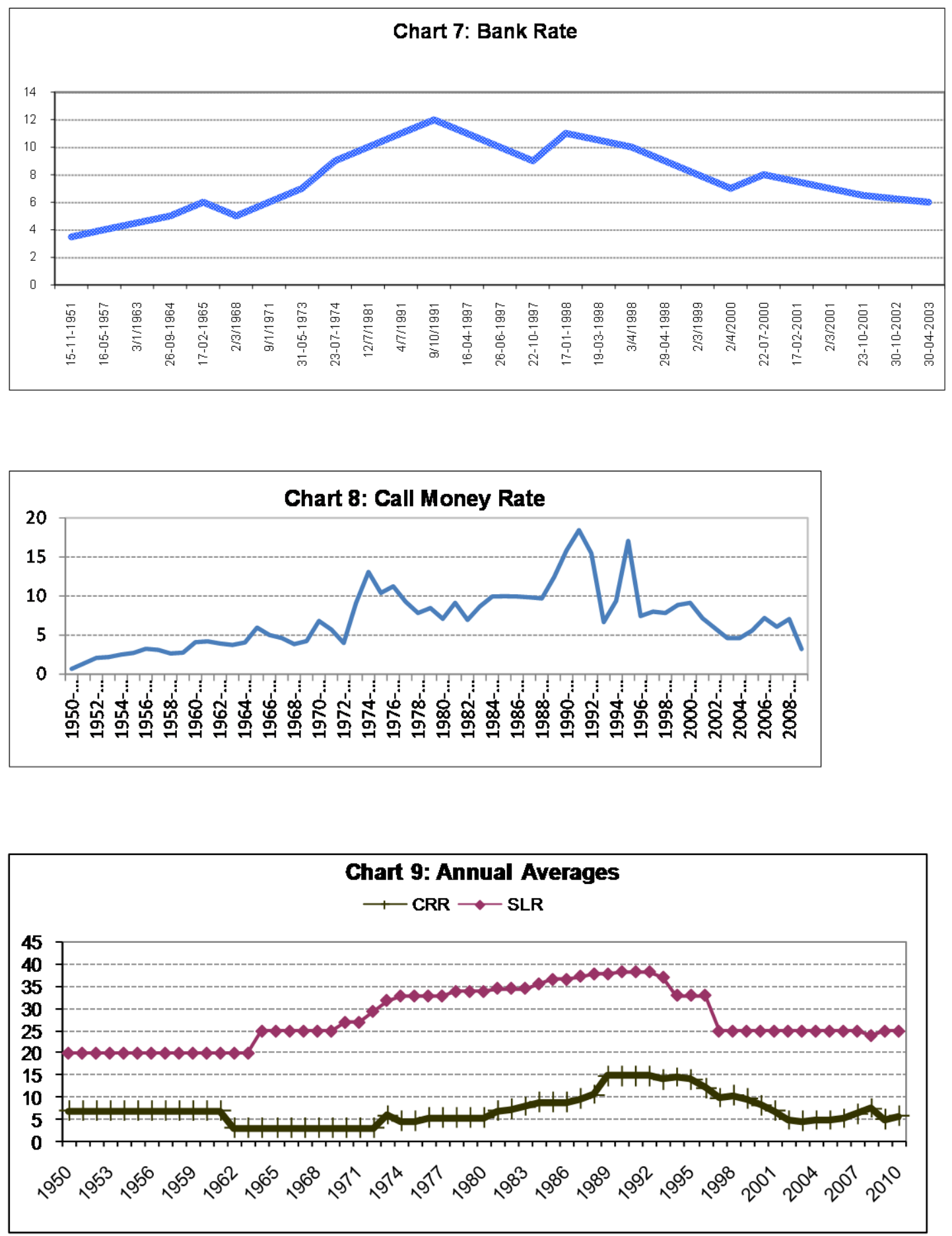


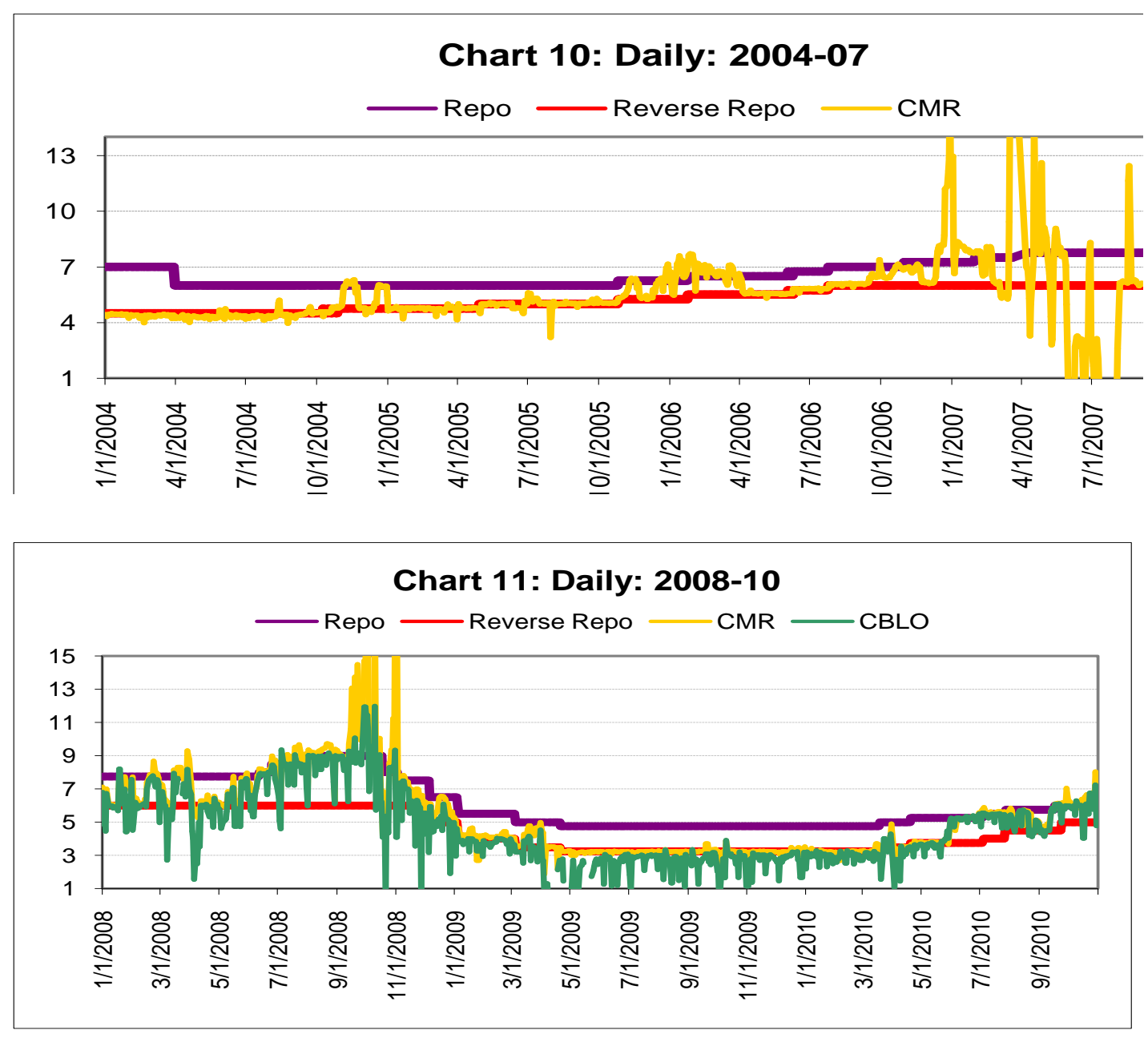

\section{Chart 12: Transmission of RBI Repo Rates}

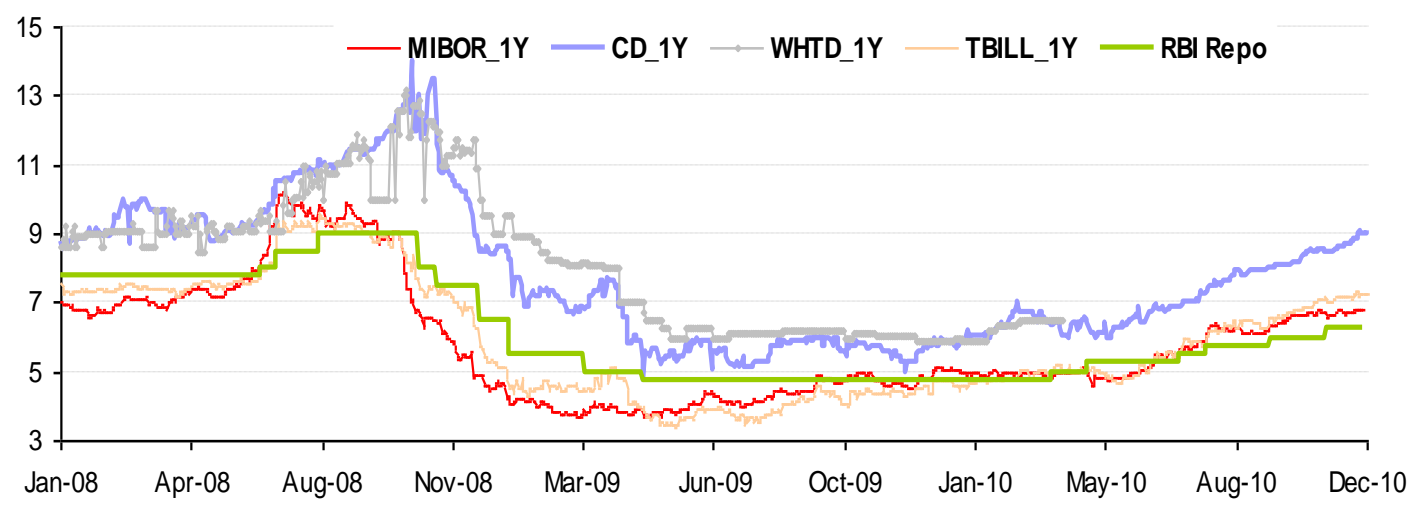

Source: RBI (2011)

Chart 9 shows the SLR and CRR rates peaking (at respectively 37.25 and 14.75) in the early nineties, and then coming down as the repressed financial regime was dismantled. The RBI absorbed liquidity at the reverse repo and injected it at the repo. Charts 10 and 11 show the bands created by the repo and reverse repo rates as the 
LAF matured and was actively used after 2004. By this time most of the sector refinance facilities had been wound up. Chart 10 gives the daily CMR. This peaked briefly in 2007 when the RBI limited borrowing in the LAF to encourage the development of the inter-bank market. The collateralized borrowing and lending market was developed and these CBLO rates are also shown in Chart 11. Since lending was based on collateral, market rates could be above the upper band during periods of tight liquidity when collateralizable securities were exhausted as in 201011. But for much of the period rates hugged the lower band as the RBI used the LAF to absorb excess liquidity generated by large foreign inflows. So the volatility of call money rates, although reduced, was still appreciable since they could jump from one edge of the band to the other.

Chart $^{22} 12$ shows how the short policy rates began to influence longer maturity rates through the term structure, demonstrating one leg of active monetary transmission through rates. Policy was working now with both price and quantity variables. There were large autonomous changes in liquidity due to forex inflows, variations in government cash balances held with the RBI and banks behaviour. Continued use of CRR changes also added to jumps in liquidity. The RBI was not able to forecast and fine-tune liquidity sufficiently to keep the CMR in the middle of the band. This was also insufficient appreciation that now policy had to act through the cost of funds or a shifting of the band, rather than liquidity squeeze. The latter was not compatible with keeping interest rates within the band.

Following the recommendations in RBI (2011) these issues were sought to be addressed by making the repo rate the signal of the policy stance with a marginal standing facility (MSF) at 100 basis points above and absorption at 100 basis points below the repo rate. The MSF would make liquidity available upto one percent of the SLR. Steps were also taken to improve liquidity forecasting and reduce transaction costs in accessing liquidity from the RBI, so as to allow finer tuning of liquidity requirements and smoother adjustment of market rates.

\footnotetext{
${ }^{22}$ This chart was part of the background papers prepared for RBI (2011).
} 


\section{V.5 The global crisis, response and revelation of structure}

Inflation rose after the severe international food price and oil shocks over 2007-08 prompted a steep monetary tightening despite slowing industrial output. The global crisis worsened the crash in industrial output. International credit froze, trade fell, domestic liquidity dried up due to outflows, and fear stalled consumption and investment plans. The global push for concerted macroeconomic stimulus allowed Indian macroeconomic policy, despite high government debt, to be countercyclical for the first time. Fiscal stimulus amounted to about 3 percent of GDP. RBI made available potential primary liquidity of about 7 percent of GDP. Just after the crisis India was regarded as a high-risk country with low fiscal capacity, but the rapid monetary-fiscal response helped give it a V-shaped recovery with one of the highest growth rates (6.7 percent). The financial system remained sound. The potential of countercyclical macroeconomic policy was demonstrated.

Shocks hitting the economy serve as useful experiments helping to reveal its structure. Consider the summer of 2008. The economy was thought to be overheating after a sustained period of over 9 per cent growth. International food and oil spikes had contributed to high inflation. The sharp monetary tightening raising short rates above 9 per cent in the summer of 2008, and the fall of Lehman in September, that froze exports, were large demand shocks hitting the economy. Industrial output fell sharply in the last quarter, but WPI based inflation only fell with oil prices in the end of the year, and CPI inflation remained high. Demand shocks with a near vertical supply curve, should affect inflation more than output. But the reverse happened. Output growth fell much more than inflation.

The V shaped recovery, which set in by the summer of 2009, also indicated a reduction in demand rather than a leftward shift of a vertical supply curve. A destruction of capacity would be more intractable; recovery would take longer. Since labour supply ultimately determines potential output for the aggregate economy, the region has a large potential.

Such outcomes are possible only if inflation is supply determined, but demand determines output. This is the precise sense in which the economy is supply constrained. Components of demand such as consumer durable spending, housing, 
etc. are interest sensitive. During the crisis, the lag from policy rates to industry was only 2-3 quarters for a fall and one quarter for a sharp rise. Policy rates have impacted output growth since 1996. Supply constraints affect inflation ${ }^{23}$.

The crisis response was fast but the resurgence of inflation before recovery was firmly established led to policy dilemmas regarding exit. The sharp resurgence of WPI inflation by Q3 of 2009 was regarded as surprising since industry had barely recovered. But it should have been expected given the impact of sustained high CPI inflation on wages. Because of the latter, the manufacturing price index fell only for a few months, and had risen to its November 2008 value of 203 by April 2009. A booming economy does add pricing power, but supply side shocks explain even manufacturing inflation. Arguments that the economy was overheating were probably incorrect because of the sharp rebound in investment after the four-quarter slump, while growth in private consumption and bank credit remained low. Growth in government consumption also slowed sharply as investment recovered. But not enough was done to anchor inflationary expectations and to reduce constraints in agricultural markets. A poor monsoon in 2009 and protracted rains in 2010 aggravated food price inflation. CPI inflation finally began to fall with a bumper harvest in 2011.

The response to early signs of industrial inflation was delayed, given the very large cut in interest rates that had to be reversed. The delay led to too fast a pace of increase in interest rates ${ }^{24}$ and to quantitative tightening. The latter contributed to volatility in interest rates and in industrial output. Government expenditure pumped into the informal sector increased demand for food. Demand for currency actually increased and financial dis-intermediation occurred. Financing for firms was coming from abroad as domestic credit growth remained slow. Firming oil prices added to wage pressures from food inflation and costs rose. Liquidity remained tight and demand contracted. Growth in industrial production softened and that in investment also fell sharply in Q1 of 2011. As elasticities increase and systems become more complex, blunt instruments should be phased out, and policies designed to reduce sharp changes.

\footnotetext{
${ }^{23}$ Parts of these arguments have also been made in Goyal (2011a, 2012)

${ }^{24}$ The operative rate went from the reverse repo at 3.25 in March 2010 to the repo at 7.5 by June 2011.
} 
If policy is better based on structure and shocks, it could more successfully smooth cycles and maintain growth. The events bring out frequent supply shocks and also show a large impact of demand on output, and of supply shocks on inflation. As higher growth paths became well established, the AD AS analysis of section III becomes more applicable. Although the longer-run aggregate supply is elastic given youthful populations in transition to more productive occupations, it is subject to frequent negative supply shocks (Figure 1).

With a supply shock as a result of monsoon failure or international oil price rise, the aggregate supply curve in the figure shifts upward and this leads to higher inflation. If in response, a demand contraction shifts the aggregate demand curve downward, this reduces inflation only marginally and at a high cost in terms of output lost. Policy should instead restrict demand just sufficiently to prevent inflationary wage and price expectations shifting up the supply curve, while encouraging supply-side improvements that can shift down the AS curve. The relative elasticities of AS and $\mathrm{AD}$ curves suggest a rethink $\mathrm{f}$ the common argument that pricing power of firms rises when demand is high. Firms tend to pass on cost shocks because of the rise in intramarginal costs.

It is difficult to come across unemployment estimates, but these numbers are large. In the developed countries, output is regarded as below potential because the crisis left 22 million unemployed. In India, the over 300 million below the poverty line are not meaningfully employed. Given the youthful demographic profile, 10-12 million are expected to enter the labour force every year. The Planning Commission estimates it will take growth at ten percent per annum together with an employment elasticity of 0.25 to absorb them. Since peak levels of domestic savings plus inflows had reached 40 percent of GPD, with an incremental capital output ratio of 4 , this gives ten per cent rate of growth. This could be regarded as the potential output. The RBI, however, defines full capacity as the potential output of the small manufacturing sector, even though in India, for example, this accounts for only 25 per cent of the output and 5 per cent of the employment. The economy is considered to be supply constrained. Figure 1 helps understand how exactly the economy is supply constrained and better captures the macroeconomic structure of an economy in transition. The economy is supply 
constrained in the sense inefficiencies on the supply side perpetuate inflation although output is largely demand determined. Demand contractions amplify shocks, but are not major independent sources of shocks.

Political and institutional features also result in a fiscal-monetary coordination such that the economy remains on an elastic stretch of the aggregate supply curve. Fiscal populism pushes monetary authorities towards conservatism in order to reduce inflationary expectations. But since the populism raises inefficiencies and therefore costs it shifts up the supply curve, while monetary tightening reduces demand, resulting in a large negative effect on output for little gain in reduced inflation. For the RBI to be accommodating, restraint on revenue deficits and populist expenditure is necessary.

\section{V.6 Trends in money and credit}

The trends in money ${ }^{25}$ over the decades demonstrate the policy issues we have surveyed. Table 12 shows much more fluctuations in the rate of growth of RM compared to other types of money. Rates of growth for all types increased substantially after the first two decades, demonstrating the increasing monetization of the economy. This was especially rapid from the eighties as the jump in time deposit to GDP ratio, and of broad money, of which it is a component, indicates. The jump in time deposit ratios reflects the rise in savings ratios in the eighties to above 20 percent (Table 4). The expansion in bank branches partly caused this rise.

\footnotetext{
${ }^{25}$ RBI definitions of reserve money from the components side are: Currency in circulation + Banker's deposits with the RBI+ other deposits with the RBI, and from the sources side: RBI's domestic credit + Govt's currency liabilities to the Public+Net FX assets of RBI other items. The definitions of broad money from the components side are: Currency with the public + Aggregate deposits with banks, and from the sources side are: Net bank credit to government (Net RBI credit to central and state governments + other banks' credit to government) + Bank credit to commercial sector (RBI+ other banks) + Net forex assets of banking sector (RBI+ other banks) + Government's currency liabilities to the public - banking sector's net non-monetary liabilities. These were followed in deriving the series given in the tables.
} 


\begin{tabular}{|c|c|c|c|c|c|c|}
\hline \multicolumn{7}{|c|}{ Table 12: Trends in Money } \\
\hline & & $\begin{array}{l}\text { Reserve } \\
\text { Money } \\
\end{array}$ & $\begin{array}{l}\text { Narrow } \\
\text { Money }\end{array}$ & $\begin{array}{l}\text { Broad } \\
\text { Money } \\
\end{array}$ & $\begin{array}{l}\text { Demand } \\
\text { Deposits }\end{array}$ & $\begin{array}{l}\text { Time } \\
\text { Deposits }\end{array}$ \\
\hline \multicolumn{7}{|c|}{ Average Annual Growth Rate } \\
\hline $1951-52$ to $1959-60$ & & 4.3 & 3.74 & 5.94 & 3.22 & 15.62 \\
\hline $1960-61$ to $1969-70$ & & 7.6 & 9.18 & 9.57 & 12.63 & 10.61 \\
\hline $1970-71$ to $1979-80$ & & 14.88 & 12.17 & 17.27 & 13.54 & 24.7 \\
\hline $1980-81$ to $1989-90$ & & 16.5 & 15.09 & 17.21 & 15.82 & 18.29 \\
\hline $1990-91$ to $1999-00$ & & 13.87 & 15.62 & 17.17 & 16.32 & 17.98 \\
\hline $2000-01$ to $2009-10$ & & 15.42 & 16.02 & 17.46 & 17.57 & 18.09 \\
\hline \multicolumn{7}{|c|}{ Average Ratio to GDP Market Price (percentage) } \\
\hline $1951-52$ to $1959-60$ & & 13.2 & 17.47 & 22.02 & 5.11 & 4.55 \\
\hline $1960-61$ to $1969-70$ & & 11.46 & 15.75 & 21.84 & 4.98 & 6.09 \\
\hline $1970-71$ to $1979-80$ & & 10.99 & 16.2 & 29.24 & 7.02 & 13.04 \\
\hline $1980-81$ to $1989-90$ & & 13.84 & 15.74 & 41.98 & 6.58 & 26.24 \\
\hline $1990-91$ to $1999-00$ & & 15.28 & 17.47 & 51.33 & 7.71 & 33.85 \\
\hline $2000-01$ to $2009-10$ & & 16.22 & 21.18 & 74.8 & 9.81 & 53.62 \\
\hline \multicolumn{7}{|c|}{ Table 13: Decadal Averages } \\
\hline & $D / R$ & $\mathrm{D} / \mathrm{C}$ & $\begin{array}{l}\text { Mon } \\
\text { Mult }\end{array}$ & & M3/RM & GDP/M3 \\
\hline $1953-54$ to $1959-60$ & 21.61 & 0.79 & 1.73 & & 1.69 & 4.70 \\
\hline $1960-61$ to $1969-70$ & 28.09 & 1.09 & 2.01 & & 1.93 & 4.83 \\
\hline $1970-71$ to $1979-80$ & 19.50 & 2.12 & 2.72 & & 2.66 & 3.77 \\
\hline $1980-81$ to $1989-90$ & 8.07 & 3.45 & 3.09 & & 3.12 & 2.58 \\
\hline $1990-91$ to $1999-00$ & 8.29 & 4.18 & 3.43 & & 3.37 & 2.11 \\
\hline $2000-01$ to $2009-10$ & 14.80 & 5.42 & 4.67 & & 4.73 & 1.46 \\
\hline
\end{tabular}

Table 13 presents select monetary ratios: The money multiplier and its determinants; the aggregate deposits to bank reserves ratio (D/R); aggregate deposits to currency ratio $(\mathrm{D} / \mathrm{C})$. Currency and reserves are the quantity variables that can be affected by the $\mathrm{CB}$. For example, the $\mathrm{CB}$ can increase currency by printing more money and it can similarly increase reserves by requiring a higher percentage of deposits to be stored in the CB.

The steady rise in D/C also reflects monetization of the economy. It also demonstrates confidence in the financial system, and the absence of inflation high enough to induce a flight from money. The fall in D/R from the 1970s was a consequence of the sharp rise in CRR. This was unable to prevent a rise in M/RM but it did slow down its increase in the eighties and nineties compared to the last decade. The last column 
GDP/M is a measure of velocity. The latter fell through all the decades, showing a well-managed financial expansion, and a positive income elasticity of money demand $^{26}$. Income elasticity was rising because of expansion of bank branches but lack of other financial instruments, probably tended to decrease it. GDP/M did rise for a few years in the inflationary seventies, as did the GDP/C ratio. The GDP of the nation rose as it became a trillion dollar plus economy. But the stock of money, essential for lubricating commerce, rose even faster.

\begin{tabular}{|c|c|c|c|c|c|c|c|c|c|}
\hline \multicolumn{10}{|c|}{ Table 14: Trends in Credit } \\
\hline & $\begin{array}{l}\text { Net } \\
\text { RBI } \\
\text { Credit } \\
\text { to } \\
\text { Central } \\
\text { Govt. } \\
\end{array}$ & $\begin{array}{l}\text { Net RBI } \\
\text { Credit to } \\
\text { State } \\
\text { Govt. }\end{array}$ & $\begin{array}{l}\text { Net } \\
\text { RBI } \\
\text { Credit } \\
\text { to } \\
\text { Govt. } \\
\end{array}$ & $\begin{array}{l}\text { Other } \\
\text { Banks } \\
\text { Investme } \\
\text { nt in } \\
\text { Govt. } \\
\text { Securities }\end{array}$ & $\begin{array}{l}\text { Net } \\
\text { Bank } \\
\text { Credit to } \\
\text { Govt. }\end{array}$ & $\begin{array}{l}\text { RBI } \\
\text { Credit to } \\
\text { Commerc } \\
\text { ial Sector }\end{array}$ & $\begin{array}{l}\text { Other } \\
\text { Bank's } \\
\text { Credit to } \\
\text { Commerc } \\
\text { ial Sector }\end{array}$ & $\begin{array}{l}\text { Total } \\
\text { Bank } \\
\text { Credit to } \\
\text { Commerci } \\
\text { al Sector }\end{array}$ & $\begin{array}{l}\text { Total } \\
\text { Bank } \\
\text { Credit } \\
\end{array}$ \\
\hline \multicolumn{10}{|c|}{ Average Annual Growth Rate } \\
\hline $\begin{array}{l}1961-62 \text { to } \\
1969-70 \\
1970-71 \text { to }\end{array}$ & & & 7.12 & 8.9 & 7.5 & 30.42 & 16.15 & 15.45 & 10.94 \\
\hline $\begin{array}{l}1979-80 \\
1980-81 \text { to }\end{array}$ & 14.19 & 27.02 & 13.93 & 20.34 & 15.58 & 38.47 & 18.7 & 19.13 & 17.54 \\
\hline $\begin{array}{l}1989-90 \\
1990-91 \text { to }\end{array}$ & 19.9 & 29.47 & 19.69 & 19.18 & 19.41 & 15.81 & 17.31 & 17.21 & 18.09 \\
\hline $\begin{array}{l}1999-00 \\
2000-01 \text { to }\end{array}$ & 7.12 & 18.41 & 7.49 & 21.15 & 14.22 & 10.63 & 14.76 & 14.56 & 14.37 \\
\hline $2009-10$ & -580.8 & 0.42 & -510.58 & 17.71 & 14.81 & 42.75 & 19.98 & 19.68 & 17.56 \\
\hline \multicolumn{10}{|c|}{ Average Ratio to GDP Market Price at Current Price (Percentage) } \\
\hline $\begin{array}{l}1960-61 \text { to } \\
1969-70 \\
1970-71 \text { to }\end{array}$ & & & 10.02 & 3.02 & 13.04 & 0.14 & 9.55 & 9.69 & 22.74 \\
\hline $\begin{array}{l}1979-80 \\
1980-81 \text { to }\end{array}$ & 8.39 & 0.66 & 8.96 & 4.51 & 13.57 & 0.81 & 17.77 & 18.57 & 32.14 \\
\hline $\begin{array}{l}1989-90 \\
1990-91 \text { to }\end{array}$ & 12.79 & 0.55 & 13.34 & 7.3 & 20.65 & 1.14 & 27.26 & 28.39 & 49.05 \\
\hline $\begin{array}{l}1999-00 \\
2000-01 \text { to }\end{array}$ & 10.6 & 0.28 & 10.88 & 11.77 & 22.65 & 0.75 & 27.98 & 28.73 & 51.39 \\
\hline $2009-10$ & 2.08 & 0.17 & 2.24 & 21.32 & 23.5 & 0.15 & 43.45 & 43.6 & 67.17 \\
\hline
\end{tabular}

Table 14 shows the creation of credit, on which the monetary policy was explicitly focused for much of the period. The steepest rise in credit/GDP ratios came, however, after liberalization. India's credit/GDP ratio is low by world standards and must rise. But a sudden sharp rise often leads to a financial crisis. Rates of growth of credit were however always moderate. Also noteworthy, in Table 14, is the sharp fall in RBI's credit to the Government, following the termination of ad hoc treasury bills, and the

\footnotetext{
${ }^{26}$ In the US, for example, velocity fell until 1948, the period of expansion of banks, and rose after that.
} 
imperatives of sterilization of large inflows. Other bank credit to the Government rose. Banks often voluntarily held Gsecs in excess of lowered SLR requirements, as rates and returns became attractive.

\begin{tabular}{|c|c|c|c|c|c|}
\hline & & \multirow[b]{2}{*}{$\begin{array}{l}\text { Ratio of Net } \\
\text { Foreign } \\
\text { Assets of the } \\
\text { RBI to RM }\end{array}$} & \multirow{3}{*}{$\begin{array}{l}\text { Share of } \\
\text { G } \\
\text { Securities } \\
\text { in Other } \\
\text { Bank } \\
\text { Credit }\end{array}$} & \multirow{3}{*}{$\begin{array}{l}\text { Share of } \\
\text { Commercial } \\
\text { Credit in } \\
\text { Other Bank } \\
\text { Credit }\end{array}$} & \multirow{3}{*}{$\begin{array}{l}\text { Change in } \\
\text { Forex Reserves } \\
\text { as a Ratio of } \\
\text { Current } \\
\text { Account of BOP } \\
\text { (+, increase) }\end{array}$} \\
\hline \multirow[t]{2}{*}{ Decades } & $\begin{array}{l}\text { Ratio of Net } \\
\text { Domestic Assets } \\
\text { of the RBI to RM }\end{array}$ & & & & \\
\hline & Percentage & Percentage & & & \\
\hline $1960-61$ to $1969-70$ & & 5.45 & 24.17 & 75.83 & 0.098 \\
\hline $1970-71$ to $1979-80$ & 80.35 & 19.65 & 20.13 & 79.87 & 0.641 \\
\hline $1980-81$ to $1989-90$ & 89.33 & 10.67 & 21.04 & 78.96 & -0.069 \\
\hline $1990-91$ to $1999-00$ & 62.13 & 37.87 & 29.5 & 70.5 & 1.69 \\
\hline $2000-01$ to $2009-10$ & $-3.92 *$ & 108.56 & 33.36 & 66.63 & 1.42 \\
\hline
\end{tabular}

Although the size of the retail Gsecs market had seen a large rise, the fear of adversely affecting rates and increasing the cost of Government borrowing restrained the RBI's use of OMOs. Complicated restraints on Gsecs and split between capital and interest with mark to market only for the part not held to maturity continued to make Gsecs attractive to banks and to prevent them from selling when they could make capital gains. The need for such complicated restraints will reduce as a smaller share of held to maturity category and more interest rate volatility forces banks to hedge interest rate risks. Apart from OTC derivatives, markets for interest rate futures have also been developed.

Creating retail depth in the holding of Gsecs, and reducing the relative size of government borrowing from the domestic financial sector, will help the RBI to move more fully towards interest rate rather than money supply or credit variables as instruments. A push for change will come from the new Basel III prudential norms, which are unlikely to accept a forced statutory holding of even A class securities as providing a liquidity buffer. The new IFRS accounting norms will also require marking holdings of Gsecs to market.

In advanced countries as debt shares declined, independent debt management offices were created. It was thought separating monetary policy from the management of the 
Government debt, would reduce conflicts of interest. India was set to also follow this reform path. But as post crisis debt levels in these countries rose sharply CBs market tactics ca be important in maintaining the confidence of market participants and smooth functioning of debt markets (Goodhart 2010). Given the relatively high levels of Government debt, the RBI had long been using such tactics to manage government borrowing requirements. Other countries seem to be converging to India's current practices even as India tries to converge to earlier norms. This underlines again that market development cannot mean blindly aping practices elsewhere. Adapting to local needs and structure is important.

Table 15 shows the rising share of Gsecs in the commercial banks portfolio, and the consequent fall in share of commercial credit. The contribution of net domestic assets (NDA) to RM became negative as large net foreign assets (NFA) displaced them in the RBI's balance sheet. Additions to foreign exchange reserves, driven by capital flows, exceeded the current account by a large margin. Since reserves responded to volatile inflows on the capital account, while the current account was in deficit, they were a valid precautionary measure.

\section{Conclusion}

Money and monetary policy are slippery concepts, and reality is often not what it seems on a surface reading. But careful fact-based analysis can yield interesting insights. There is two-way causality between money and nominal income. But during large supply shocks, policy shocks can be treated as exogenous. Such shocks are used in this study to understand the structure of the economy. These suggest that policy was sometimes exceedingly tight when the fear, and the common understanding, was opposite: of a large monetary overhang. In focusing on financing the Government, rather than on domestic cycles, policy was procyclical-too accommodative in good times and tight in bad times.

Fiscal dominance pushed monetary policy to be too tight or too loose to compensate. An intellectual climate that encouraged government intervention and advocated a big push for development favoured the dominance of fiscal policy. These ideas became embedded in institutions and created path dependence-it was difficult to break out on a new path. The balance of payments crisis and the change in intellectual ideas 
provided the opportunity. The initial swing was too much in favour of markets, but a series of international currency and financial crisis have helped to moderate orthodoxy. It has become possible to devise a middling through path that suits Indian democracy and structure. The global crisis evoked a refreshing and apt policy stance that helped the economy retain high growth. But improvements are still required in inflation management.

When the dominant ideas of the time supported closed capital-intensive importsubstituting growth, Vakil and Brahmananda (1956) pointed out the importance of the wage goods constraint. Relieving the latter required more attention on increasing agricultural productivity and on openness. But the closing of the economy that condemned India to many years of stagnation happened because intellectual opinion was too susceptible to external ideas, and neglected more robust ideas based on a close understanding of own context.

The currently dominant ideas, favouring gradual liberalization, should aid India in its catch-up period of high growth and beyond, providing high productivity employment for its billion plus people. But that tailoring to context continues to be required. A non-ideological middling through approach makes a pragmatic adaptation to context possible. For monetary policy the three factors that cause a loss of autonomygovernments, markets and openness - are conveniently moderating each other. Thus markets are moderating fiscal profligacy; crises are moderating markets and openness. And institutions are slowly strengthening in adapting to the new ideas.

The many changes recorded in this history, demonstrate the dynamism displayed by the economy, its institutions and policy, countering the argument that democracies are doomed to stagnation. An example of change is the behaviour of interest rates. Although liberalization initially increased the volatility of rates in a thin market, it eventually brought down the volatility to levels prevailing when rates were tightly administered, as markets deepened. But now the rates came through a robust interaction between markets, institutions and policy.

In the mid-nineties, in thin markets and with greater monetary autonomy combined with unhealthy government finances, there were sharp peaks in policy and market 
rates that hurt growth. But after the global financial crisis, when fiscal responsibility legislation, higher growth and better tax administration had improved government finances, monetary-fiscal coordination was better and India came through in good shape. The future will see these years as transformative for India and its institutions. Sometimes the best haste is made slowly.

\section{References}

Agarwal A. 2008. 'Inflation Targeting in India: An Explorative Analysis', Chapter 2, unpublished IGIDR PhD thesis.

Anjaneyulu, D., Singh, D. and TCA Srinivasa Raghavan. 2010. Untitled ms "History of Monetary Policy 1900 to Independence".

Balakrishna, P. 1994. "How best to model inflation in India". Journal of Policy Modeling. pp. 677-83. December.

Balachandran, A. 1998. “The Reserve Bank of India, 1951-1967” Oxford University Press

Blanchard, O., G. D’Aricca, and P. Mauro. 2010. "Rethinking Monetary Policy”, IMF

Blinder, A. S., Ehrmann, M., Fratzscher, M., Haan, J. D., and Jansen, D.J. 2008. "Central Bank Communication and Monetary Policy: A Survey of Theory and Evidence". Journal of Economic Literature, 46(4), 910-945.

Brahmananda, P.R. 2001. "Money Income Prices in $19^{\text {th }}$ Century India". Himalaya Publishing House

Chandavarkar, A. 2005. "Towards an Independent Federal Reserve Bank of India". Economic and Political Weekly, August 27, pp. 3837-3845.

Chitre, V.S. 1986. "Quarterly Prediction of Reserve Money Multiplier and Money Stock in India", Artha Vijnana, 28, 1-123.

Christiano, L.J., M.Eichenbaum and C.L.Evans. 1999. "Monetary Policy Shocks: What Have We Learned and to What End?" Handbook of Macroeconomics, Volume1, Chapter 2, 65-148

Clarida, R., Gali, J. and Gertler, M. 2001. "Optimal Monetary Policy in Closed Versus Open Economies: An Integrated Approach", American Economic Review, 91(2), May 248-252.

Clarida, R., Gali, J. and Gertler, M. 1999. "The Science of Monetary Policy: A New Keynesian Perspective”, Journal of Economic Literature, 37(4), pp: 1661-707 
Dash, S., and A. Goyal. 2000. "The Money Supply Process in India: Identification, Analysis and Estimation", Indian Economic Journal, July-September, Volume 48, No.1.

Friedman, M. and A. J. Schwartz. 1971. "A Monetary History of the United States", 1867-1960, Princeton University Press.

GFI. 2010. "Drivers and Dynamics of Illicit Financial Flows from India: 1948-2008". Available at http://india.gfip.org

Gokarn, S. 2011. "The Price of Protein". Macroeconomics and Finance in Emerging Market Economies, 4(2).

Goodhart, C. 2010. "The Changing Role of Central Banks". BIS Working Papers no 326. www.bis.org/list/wpapers/index.htm

Goodhart, C. 2007. "The Continuing Muddles of Monetary Theory: A Steadfast Refusal to Face Facts", (mimeo), Financial Markets Group, London School of Economics.

Goyal. A. 2012. "India's Fiscal and Monetary Framework: Growth in an Opening Economy", Macroeconomics and Finance in Emerging Market Economies, 5(1), and Chapter 12 in Goyal A. (ed.) Macroeconomics and Markets in India. UK: Routledge. Earlier version available at http://www.igidr.ac.in/pdf/publication/WP-2010-025.pdf.

Goyal, A. 2011a. "Exchange Rate Regimes and Macroeconomic Performance in South Asia", in Raghbendra Jha (ed.) Routledge Handbook on South Asian Economies.

Goyal, A. 2011b. "A General Equilibrium Open Economy Model for Emerging Markets: Monetary policy with a dualistic labor market", Economic Modelling, 28 (2), 1392-1404.

Goyal, A. 2010."Inflationary Pressures in South Asia”, Asia-Pacific Development Journal, 17 (2), 1- 42, December.

Goyal, A. 2009. "Financial crises: reducing pro-cyclicality", Macroeconomics and Finance in Emerging Market Economies. 2(2), 173 - 183, March.

Goyal, A., R. A. Nair and A. Samantaraya. 2009. "Monetary Policy, Forex Markets, and Feedback Under Uncertainty in an Opening Economy". Development Research Group, Department of Economic Analysis and Policy, Reserve Bank of India, Mumbai, Study No. 32. Available at http://rbidocs.rbi.org.in/rdocs/Publications/PDFs/DRGMP030909.pdf.

Goyal, A. 2008a. "Incentives from Exchange Rate Regimes in an Institutional Context", Journal of Quantitative Economics, January \& July, 6 (1\&2), 101-121. 
Goyal, A. 2008b. "Macroeconomic Policy and the Exchange Rate: Working Together?" Chapter 7 in India Development Report 2008, R. Radhakrishna (ed.), pp. 96-111, New Delhi: IGIDR and Oxford University Press.

Goyal, A. 2007. "Tradeoffs, Delegation and Fiscal-monetary Coordination in a Developing Economy”, Indian Economic Review, 42(2), July-Dec.

Goyal, A. 2005. "Reducing Endogenous Amplification of Shocks from Capital Flows in Developing Countries," GDN project report, available at http://www.gdnet.org/pdf2/gdn_library/global_research_projects/macro_low_income/ Goyal.pdf.

Goyal, A. and Pujari, A. 2005. "Identifying Long-run Supply Curve in India", Journal of Quantitative Economics, 3, 2, 1-14.

Goyal A. 2004. "The Impact of Structure and Openness on the Causal Ordering of Interest, Inflation and Exchange Rates", Journal of Quantitative Economics, Special Issue in Memory of M. J. Manohar Rao, 2 (2), 223-242, July.

Goyal A. 2003. "Budgetary Processes: A Political Economy Perspective", Chapter 2.2 in India Infrastructure Report 2003, Public Expenditure Allocation and Accountability, Morris S. (ed.), New Delhi: 3iNetwork and Oxford University Press, 2003.

Goyal, A. 2002. "Coordinating Monetary and Fiscal Policies: A Role for Rules?" Chapter 11 in the India Development Report, Kirit S. Parikh and R. Radhakrishna (ed.), IGIDR and Oxford University Press.

Goyal, A. 1999. "The Political Economy of the Revenue Deficit", in the India Development Report, K. S. Parikh (ed.), IGIDR and Oxford University Press, New Delhi.

Gupta, S.B. 1976. "Factors Affecting Money Supply: Critical Evaluation of Reserve Bank's Analysis", Economic and Political Weekly, 11, 117-128.

Gupta, S. B .1972. “Planning Neutral Money for India”, IEJ XIX, April-June.

Jadhav, N. 1990. "Monetary Modeling of the Indian Economy: A Survey", RBI Occasional Papers, 11, 83-152.

Jalan, B. 2001. "Monetary and Credit Policy for the Year 2001-2002". Statement by Dr. Bimal Jalan, Governor, Reserve Bank of India, April, available at www.cpolicy.rbi.in.

Joshi, V. and I.M.D. Little. 1994. "India: Macroeconomics and Political Economy" 1964-1991, Oxford University Press, Delhi.

Krishnamurthy, K. and Pandit, V.N. 1985. "Macroeconomic Modeling of the Indian Economy: Studies on Inflation and Growth", Delhi: Hindustan Publishing Corporation, (India). 
Mohanty, D. 2010. "Perspectives on Inflation in India". Speech given at the Bankers Club, Chennai, 28 September.

Nachane, D. M. 2003. "P R Brahmananda; Obituary". Economic and Political Weekly. pp: 870-872. March.

Nachane, D.M. and Ray, D. 1989. "The Money Multiplier: A Reexamination of Indian Evidence”, The Indian Economic Journal, 37, 56-73.

Radcliffe Report (Report of the Committee on the Working of the Monetary System, 1958-59, Cmnd 827) http://www.jstor.org/stable/138787.

Rakshit, M. 2009. "Money and Finance in the Indian Economy", Selected papers, Vol II, Oxford University Press- New Delhi.

Rangarajan, C. 2004. "Select Essays on Indian Economy”, Academic Foundation, Volume 1 and 2.

Rangarajan, C. 2002. "Indian Economy: Essays On Money And Finance”, UBS Publishers.

Rao, D.C., Venkatachalam, T.R. and Vasudevan, A. 1981. "A Short-term Model to Forecast Monetary Aggregates: Some Interim Results”, RBI Occasional Papers, 2, 113-140.

Rao, M.J.M., and Singh, B. 1995. "Analytical Foundations of Financial Programming and Growth Oriented Adjustment”, DRG study, DEAP, RBI, Bombay.

Rao, V.K.R.V. 1952. "Investment, Income and the Multiplier in an Underdeveloped Economy”. The Indian Economic Review, February, reprinted in Agarwala, A.N. and S.P. Singh (eds.) The Economics of Underdevelopment, London, Oxford, New York: Oxford University Press, 205-218, 1958.

Reddy, Y.V. 2002. "Lectures on Economic and Financial Sector Reforms in India", Oxford University Press.

RBI (Reserve Bank of India). 2011. "Report of the Working Group on Operating Procedures of Monetary Policy" (Chairman: Shri D. Mohanty).

RBI (Reserve Bank of India). 1991. "Report of the Committee on the Financial System" (Chairman: Shri M. Narasimham).

RBI (Reserve Bank of India). 1987. "Report of the Working Group on the Money Market” (N. Vaghul, Chairman), Bombay.

RBI (Reserve Bank of India). 1985. "Report of the Committee to Review the Working of the Monetary System" (S. Chakravarty, Chairman), Bombay.

Singh, A., Shetty, S.L. and Venktachalam, T.R. 1982. "Monetary Policy in India: Issues and Evidence", Supplement to the RBI Occasional Paper, 3, 1-133. 
Svensson, L.E.O. 2000. “Open-economy Inflation Targeting”, Journal of International Economics, 50, 155-183.

Usha Thorat. 2010. "Learning from Crises", Macroeconomics and Finance in Emerging Market Economies, 3(2), 299 - 307.

Vakil, C.N and Brahmananda, P.R. 1956. "Planning for an Expanding Economy; Accumulation Employment and Technical Progress in Underdeveloped Countries". Vora and Co: Bombay.

Vasudevan, A. 1977. "Demand for Money in India- A Survey of Literature", Reserve Bank Staff Occasional Papers. Vol 2, June.

Vasudevan, A. 2005. "On Central Bank Reforms". Economic and Political Weekly. Vol 40 (42) October 15. Available at http://beta.epw.in/newsItem/comment/61761/

V.G. Pendharkar and M. Narasimham. 1966. "Recent Evolution of Monetary Policy in India”, Reserve Bank of India Bulletin, April, pp. 340-61.

Woodford, M. 2003. Interest and Prices: Foundations of a Theory of Monetary Policy, New Jersey, Princeton University Press. 